\title{
Probiotics Mitigates Skeletal Muscle Atrophy in Isoproterenol- Induced Heart Failure Adult Rats; by Increasing IGF-I Gene Expression and Improving Insulin Sensitivity
}

\author{
MANAL S. ABD-EL HAMID, M.D.*; ABD EL-HAMID A. MOHAMED, M.D.* and \\ NAYRA S.H. MEHANNA, Ph.D.** \\ The Department of Physiology, Faculty of Medicine, Ain Shams University* and The Department of Dairy Science, \\ National Research Centre, Dokki**, Cairo, Egypt
}

\begin{abstract}
Background: Skeletal muscle atrophy is a common complication of heart failure that may result from the accompanying neuro-hormonal disturbances. Altered gut microbiome can mediate these neuro-hormonal disturbances. Growing evidences pointed to the health benefits of probiotics.

Aim of Study: To evaluate the effects of probiotics on skeletal muscle state in ISO-induced HF and the underlying mechanisms.

Material and Methods: 21 male adult rats were divided into: Control group (C), ISO-HF group; rats were injected with isoproterenol (ISO) $5 \mathrm{mg} / \mathrm{kg} / \mathrm{d}$ IP for 7 days and Pro-T group which were given probiotics by oral gavage for 6 weeks after ISO injection. Plasma Ang II, insulin, glucose, skeletal muscle atrogin and cardiac BNP levels were measured. Also relative gene expression of skeletal muscle IGF-1, IRS-1, NADPH oxidase was assessed. Cardiac and skeletal muscle tissues were weighed and histopathologically assessed.

Results: In pro T group, cardiac BNP, plasma Ag II, left ventricular weight and LV/BW ratio were significant reduced. Also, skeletal muscle atrogin and NADPH oxidase were significantly decreased with a significant increase in skeletal muscle weight, IGF-1 and IRS-1 relative gene expression. In addition, probiotics decreased insulin resistance, plasma glucose, insulin levels and HOMA-IR score. This was accompanied by the restoration of normal collagen distribution and cardiac muscle distinct cell borders and skeletal muscle distinct cell borders.
\end{abstract}

Conclusion: Probiotics mitigates muscle atrophy in ISOHF by lowering Ang II and by their anti-oxidant, anti-fibrotic, anti-hypertrophic and anti-hyperglycemic effects.

Key Words: Probiotics - Isoprotrenol-induced heart failure - Angiotensin-II - Skeletal muscle atrophy - IGF1 - Muscle atrogin.

Correspondence to: Dr. Manal S. Abd-El Hamid, E-Mail: manalsaidsun@yahoo.com

\section{Introduction}

HEART Failure (HF) is a worldwide major cause of hospitalization and death [1]. Cardiac cachexia and muscle sarcopenia, a condition characterized by decreased muscle mass and strength, has been identified as a major comorbidity of heart failure [2]. This condition is characterized by muscle fibrosis, exercise intolerance, insulin resistance and poor prognosis [3].

Skeletal muscle protein synthesis depends on the integrity of Insulin Growth Factor receptors (IGF-1) and Insulin Receptor Substrate 1 (IRS-1), while muscle catabolic pathways include myostatin overexpression, the activation of ubiquitinproteasome system or the initiation of apoptotic pathways [3]

Evidences suggest that imbalance between progrowth and anti-growth signals in the skeletal muscle accompany HF [1]

Yoshida et al., [4]. Reported high levels of Ang II, the main effector molecule of the Renin Angiotensin System (RAS), in cardiac cachectic patients. Demos-Davies et al., [5] stated that Ang-II may serve as a common pathway governing cardiac and skeletal muscle pathological alterations.

Earlier, Brink et al., [6] claimed that Ang-II infusion in rats reduced circulating and skeletal muscle IGF-1 and IGF-1 binding proteins. Also, Dalla Libera et al., [7] added that AT 1 receptor blockade prevents skeletal muscle atrophy in a rat model of CHF, suggesting relationship between the RAS and skeletal muscle atrophy. 
Recently, Yang et al., [8] stated that chronic angiotensin II infusion in a rat model was associated with gut dysbiosis. Tang et al., [9] reported that altered microbiota can stimulate sympathetic system and accelerate renin secretion. Karbach et al., [10] highlighted the role of altered gut microbiota in mediating AngII-induced cardiac muscle inflammation, fibrosis and oxidative stress. Imbalanced gut microbiota can trigger muscle pro-inflammatory state and mitochondrial dysfunction [11]. Therefore, there is much awareness of the importance of microbiome manipulation with probiotics [12]

Probiotics are "live microorganisms that can be administered in adequate amounts in various forms of dietary supplements including yogurt, fermented milk and food products to confer a health benefit on the host" [13]. According to WHO [14], in order to provide health benefits, probiotics should endure human digestion, gastric juices and bile, and multiply progressively in the GI tract.

A growing research field on the health benefits of probiotics had shown that probiotic can prevent and/or treat intestinal disorders and colitis [15] induce hypo-cholesterolemic effects [16] and reduce the blood glucose levels and insulin resistance. Moreover, yogurt containing probiotic bacteria showed higher ACE-inhibitory activities [17].

A recent animal study highlighted the ability of probiotics to improve muscle mass and weakness [18]. Aerobic performance was improved in teenage female endurance swimmers after the use of probiotic yoghurt [19]. However, few studies have focused on the interaction of probiotics with the metabolic and the morphological alterations that occur in the HF-induced skeletal muscle disorders, and their possible effects in lessening or preventing these alterations.

Aim of the work: This study aimed at evaluating the skeletal muscle biochemical and morphological alterations in ISO-induced HF, as well as, the possible protective effects of probiotics on these alterations and the underlying mechanism(s), if any.

\section{Material and Methods}

\section{Experimental animals:}

This study was carried out during 2018 on 21 adult male albino rats, initially weighing 170-200 grams. Rats were purchased from the Egyptian Organization for Biological Products and Vaccines (VACSERA), and housed in animal cages (3 rats/ cage) with suitable ventilation, temperature of 22$25^{\circ} \mathrm{C}, 12$ hours light dark cycle and free access to food and water-ad libitum-in the Medical Ain Shams Research Institute (MASRI), Faculty of Medicine, Ain Shams University.

To decrease the possible discomfort of animals, they were accommodated in the animal house for 7 days prior to experimental procedures.

Animals were not exposed to unnecessary pain or stress and animal manipulation performed with maximal care and hygiene. At the end of experiment, animals sacrificed by overdose of anesthesia. Animal remains disposal occurred by incineration.

\section{Ethics Committee:}

All animal experiments were performed according to the National Institutes of Health guide for the care and use of Laboratory animals (NIH Publications No. 8023, revised 1978).

\section{Experimental design:}

Rats were allocated into three groups ( 7 rats each).

- Group I: control group(C): Rats of this group received a regular diet with free access to water, and were injected daily with normal saline IP.

- Group II: Isoprotrenol-induced heart failure group (ISO-HF): Rats of this group were injected with the catecholamine Isoproterenol in dose of 5 $\mathrm{mg} / \mathrm{kg} / \mathrm{d}$ IP for 10 days [20] to mimic heart failure syndrome.

- Group III: Probiotic treated group (Pro-T): Rats of this group were injected with Isoproterenol in dose of $5 \mathrm{mg} / \mathrm{kg} / \mathrm{d}$ IP for 10 days. Starting from the eleventh day, rats were treated with probiotics, $10 \mathrm{gm}$ orally by gavage once a day for 6 consecutive weeks [21]

\section{Drugs and probiotics:}

Isoprotrenol (ISO) was purchased from Sigma Company (Sigma-Aldrich, Germany) as a powder, and was dissolved in saline.

\section{Probiotics treatment:}

I- Microorganisms: Probiotics used in the present study was formed of multiple strains probiotics. Strains were prepared in the probiotics lab of the National Research Center (NRC). Bacterial strains used are:

- Lactobacillus rhamnosus.

- Lactobacillus acidophilus.

- Lactobacillus casai.

- Bifidobacterium breve. 
- Bifidobacterium longum.

- Streptococcus thermophilus.

II- Media: The microbial media used throughout the study had been purchased from Difco and Oxoid (Germany). All media plates were incubated anaerobically at $37^{\circ} \mathrm{C}$.

III- Preparation of the product.

Yogurt containing probiotics preparation:

1- Mixing $10 \mathrm{~g}$ of low-heat, antibiotic-free skim milk powder in $90 \mathrm{ml}$ of distilled water in a $100 \mathrm{ml}$ Erlenmeyer flask.

2- Sterilizing at $15 \mathrm{lb}$ pressure (1 .05kPa.) for $10 \mathrm{~min}$.

3- Cooling to 37C.

4- Inoculating yogurt starter with probiotic strain (s).

5- Incubating at $37 \mathrm{C}^{\circ}$ for at least $4 \mathrm{~h}$. longer if desired for $\mathrm{pH}$ versus time profile.

6- Counting of live probiotic bacterial cells.

The Bifidobacterium spp. and Lactobacillus spp. were counted by adding $1 \mathrm{ml}$ of the product to $9 \mathrm{ml}$ saline $(0.1 \mathrm{~g} / \mathrm{l})$; serial dilutions were done. Bifidobacterium spp. was counted on LP-MRS Agar and Lactobacillus spp. was counted on MRS Agar and Streptococcus spp. on M1 7 agar using pour plate technique.

IV- Enumeration of live probiotic bacterial cells.

The Bifidobacterium spp. in the fermented product was enumerated by adding $1 \mathrm{ml}$ of the product to $9 \mathrm{ml}$ saline $(0.1 \mathrm{~g} / \mathrm{l})$; serial dilutions were made. Bifidobacterium spp. was enumerated on LP-MRS Agar using pour plate technique.

The MRS agar (Oxoid, Basingstoke, UK) was dissolved in an amount of water equivalent to $93 \%$ of the final volume and sterilized at $121^{\circ} \mathrm{C}$ for 15 minutes. In the remaining water $(7 \%)$, we dissolve 0.2 grams of lithium per liter and 0.3 grams per liter of sodium propionate, which are inhibitory agents. Afterwards, this solution of antimicrobial agents was sterilized using a $0.22 \mathrm{~mm}$ filter and was carefully mixed with the MRS agar at $50^{\circ} \mathrm{C}$ in a laminar flow chamber, with avoiding the incorporation of air [22].

The plates were incubated anaerobically at $37^{\circ} \mathrm{C}$ for 72 hours; anaerobic conditions were created using (Gas generating kit anaerobic system, Oxoid, UK). Plates containing 20 to 300 colonies were enumerated and the count was expressed as $\mathrm{CFU} / \mathrm{g}$ of the product.
MRS agar [23] used to determine the counts of Lactobciluus spp. The plated incubated at $37^{\circ} \mathrm{C}$ for $48 \mathrm{~h}$ under anaerobic condition.

M17 agar medium [24] for enumerated the count of Streptococcus spp, the plates incubated at $37^{\circ} \mathrm{C}$ for $48 \mathrm{~h}$ under aerobic condition.

V- Probiotic supplementation.

Probiotic supplementation constitutes $10 \mathrm{gm}$. from rat dietary supplement, and contained probiotic strains (not less than $10 / \mathrm{g}$ for each genus). It was taken orally by gavage once a day for 6 consecutive weeks [21].

\section{Experimental procedure:}

At the end of the study, the overnight fasted rats were weighed and anaesthetized with thiopental sodium (EIPICO, Egypt), IP (40mg/kg B.W). Laparotomy was done and blood samples were withdrawn from the abdominal aorta to be centrifuged. The resulting plasma was used for measurement of plasma glucose, insulin and Ag II.

The heart was dissected, cleared from remnants, washed by cold saline, dried by filter paper and weighed in 5-Digit-Metler balance (AE 1 63). The Right Ventricle (RV) and Left Ventricle (LV) were dissected and weighed. The left ventricle tissues were cut into 2 pieces, one was used to measure cardiac tissue Brain Naturetic Peptide (BNP) and the other piece was preserved in formalin for histopathological assessment.

Both lower limbs gastrocnemius muscles were excised. Then, they were washed by cold saline, dried by filter paper and weighed. Further, the right one was used to measure skeletal muscle atrogin, Insulin Growth Factor-1 (IGF-1), Insulin Receptors Substrate (IRS-1) and NADPH oxidase relative gene expression, and the left gastrocnemius muscle was preserved in formalin for histopathological assessment.

\section{Biochemical measurements:}

Measurement of plasma glucose was performed using oxidase-peroxidase method [25].

Measurement of plasma insulin was performed using enzyme-linked immunosorbent assay ELISA kit (Dako, Carpinteria, CA) according to the method described by Delams [26].

HOMA-IR test:

To estimate insulin resistance, the Homeostasis Model Assessment for Insulin Resistance (HOMAIR: Insulin resistance index) [27] was used, calcu- 
lated as the product of fasting insulin (in fasting glucose (in $\mathrm{mmol} / \mathrm{l}$ ) divided by 22.5 . A lower index indicates greater insulin sensitivity.

Measurement of plasma Ang II was performed by quantitative rat Ang II ELISA kit (CUSABIO TECHNOLOGY LLC, Houston, TX, USA), according to the manufacturer's instructions.

Measurement of cardiac tissue brain BNP was performed in tissue homogenates of the left ventricle, using Rat BNP ELISA Kit (My BioSource, Inc., San Diego, CA, USA) according to the manufacturer's instructions.

To prepare the tissue homogenate, tissue was minced into small pieces and rinsed in ice-cold Phosphate Buffer Solution (PBS) (0.01M, pH=7.4) to remove excess blood thoroughly. Tissue pieces were weighed and then homogenized in PBS (tissue weight (g): PBS (mL) volume=1 :9) with a glass homogenizer on ice. The homogenates were then centrifuged for $5 \mathrm{~min}$ at $5000 \mathrm{Xg}$ to get the supernatant.

Measurement of skeletal muscle atrogin was performed using Rat F-box only protein 32 (FBXO32) ELISA Kit (CUSABIO TECHNOLOGY LLC, Houston, TX, USA), according to the manufacturer's instructions. To prepare the tissue homogenate, $100 \mathrm{mg}$ tissue was rinsed with $1 \mathrm{X}$ PBS, homogenized in $1 \mathrm{ml}$ of $1 \mathrm{X}$ PBS and stored overnight at $-20^{\circ} \mathrm{C}$. After performing two freezethaw cycles to break the cell membranes, the homogenates were centrifuged for 5 minutes at 5000 $\mathrm{Xg}, 2-8^{\circ} \mathrm{C}$. The supernatant was removed and stored in aliquot at $80^{\circ} \mathrm{C}$. Samples were centrifuged again after thawing before the assay.

Quantitative analysis of skeletal muscle relative gene expression of IGF-1, IRS-1 and NADPH oxidase by real time PCR:

\section{Tissue Homogenization:}

Approximately $30-40 \mathrm{mg}$ skeletal muscle tissues were placed in pre-labeled micro-centrifuge tubes placed on ice. Tissues were chopped using a sterile razor blade in a dish (kept on ice) in a drop of TRIzol reagent. Chopped tissue was transferred to a glass mortar and pestle pretreated with DEPC water for $2 \mathrm{~h} .1 \mathrm{ml}$ TRIzol reagent was added to it and homogenized well. The homogenate was transferred into a $1.5 \mathrm{ml}$ Eppendorf tube.

\section{Total RNA extraction:}

Total RNA was extracted from tissue homogenate using SV Total RNA Isolation System (Promega, Madison, WI, USA) according to manufacturer's instruction. The RNA concentrations and purity were measured with an ultraviolet spectrophotometer.

\section{Complementary DNA (cDNA) synthesis:}

The cDNA was synthesized from 1 RNA using SuperScript III First-Strand Synthesis System as described in the manufacturer's protocol (\#K1621, Fermentas, Waltham, MA, USA). In brief, 1 otal RNA was mixed with 50 oligo (dT) 20,50ng/ random primers, and $10 \mathrm{mM}$ dNTP mix in a total volume of 10 . The mixture was incubated at $56^{\circ} \mathrm{C}$ for $5 \mathrm{~min}$, and then placed on ice for $3 \mathrm{~min}$. The reverse transcriptase master mix containing 2 L $10 X$ RT buffer, 4 L C $25 \mathrm{mM} \mathrm{MgCl}_{2}, 2 \mathrm{M} 0.1 \mathrm{M}$ DTT, and 1 the SuperScript $\AA$ III RT (200U/ L) as added to the mixture and was incubated at $25^{\circ} \mathrm{C}$ for $10 \mathrm{~min}$ followed by $50 \mathrm{~min}$ at $50^{\circ} \mathrm{C}$.

\section{Real-time quantitative PCR:}

Real-time PCR amplification and analysis were performed using an Applied Biosystem with software Version 3.1 (StepOneTM, USA). The reaction contained SYBR Green Master Mix (Applied Biosystems), gene-specific primer pairs that were designed with Gene Runner Software (Hasting Software, Inc., Hasting, NY) from RNA sequences from the gene bank. Gene-specific primer pairs are shown in (Table 1).

Table (1): The primer sequence of the studied gene.

\begin{tabular}{|c|c|}
\hline & Primer sequence \\
\hline $\begin{array}{c}\text { - NADPH } \\
\text { oxidase }\end{array}$ & $\begin{array}{l}\text { - Forward prime: } 5^{\prime} \text {-AGGCTGGTTTGAGCGAGT-3' } \\
\text { - Reverse primer: } \\
\text { 5'-ATTGAATTCGGGCGTCTGCTG-3' }\end{array}$ \\
\hline • IRS-1 & $\begin{array}{l}\text { - Forward primer: } \\
\text { 5-GGACTTGAGCTATGACACGGG-3 } \\
\text { - Reverse primer: } \\
\text { 5-GCCAATCAGGTTCTTTGTCTGAC-3 }\end{array}$ \\
\hline • IGF-1 & $\begin{array}{l}\text { - Forward prime: } 5^{\prime}-\mathrm{CTTTGCGGGGCTGAGCTGGT-3'} \\
\text { - Reverse primer: } 5 \text { '-CTTCAGCGAGCAGTACA-3' }\end{array}$ \\
\hline
\end{tabular}

All primer sets had a calculated annealing temperature of $60^{\circ}$. Quantitative RT-PCR was performed in a 25- reaction volume consisting of 2X SYBR Green PCR Master Mix (Applied Biosystems), 900nM of each primer and 2 th cDNA. Amplification conditions were: $2 \mathrm{~min}$ at $50^{\circ}, 10 \mathrm{~min}$ at $95^{\circ}$ and 40 cycles of denaturation for $15 \mathrm{~s}$ and annealing/extension at $60^{\circ}$ for $10 \mathrm{~min}$. Data from real-time assays were calculated using the v1.7 sequence detection software from PE Biosystems (Foster City, CA). Relative expression of studied gene mRNA was calculated using the comparative $\mathrm{Ct}$ method. All values were normalized to beta actin which was used as the control house- 
keeping gene and reported as fold change over background levels detected in the diseased groups.

\section{Histopathological studies:}

The left gastrocnemius muscle and the left ventricle were dissected out, fixed in $10 \%$ buffered formalin at room temperature overnight. Specimens were dehydrated using alcohol, cleared in xylol formalin and embedded in paraffin. Paraffin embedded sections of 5 mesness were stained with Hematoxylin and Eosin (H \& E) and with Masson's trichrom stain [28] for subsequent blind microscopic examination.

\section{Statistical analysis:}

All results in the present study expressed as mean \pm SEM. Statistical Package for the Social Sciences (SPSS, Inc., Chicago, IL, USA) program, Version 20.0 was used to compare significance between each two groups. Comparisons were made using 1-way ANOVA (Analysis of Variance) for difference between means of different groups was performed on results obtained in the study. Differences were considered significant when $p \leq 0.05$.

\section{Results}

Results encountered in the present study are displayed in (Tables 2-4) and Figs. $(1,2)$, Histological Figs. (3-11).

\section{Marker of heart disease:}

Table (2) shows that cardiac tissue BNP and plasma Ang-II were significantly increased in the isoproterenol-induced heart failure (ISO-HF) group compared to the control (C) group. On the other hand, Probiotic treated (Pro-T) group showed a significant decreased in both of cardiac tissue BNP and plasma Ang-II compared to the ISO-HF group but their level were still significantly higher than the levels of the $\mathrm{C}$ group.

Table (2): Cardiac tissue Brain Natriuretic Peptide (BNP) $(\mathrm{Pg} / \mathrm{mg})$ and Plasma Angiotensin II (AgII) (Pg/ml) in the different studied groups (mean \pm SEM).

\begin{tabular}{llll}
\hline & \multicolumn{1}{c}{ Control } & ISO-HF & \multicolumn{1}{c}{ Pro-T } \\
\hline Cardiac BNP (Pg/mg) & $28.91 \pm 2.63$ & $95.35 \pm 8.52 \mathrm{a}$ & $75.94 \pm 2.87 \mathrm{ab}$ \\
Plasma AgII (Pg/ml) & $3.12 \pm 0.37$ & $19.77 \pm 2.11 \mathrm{a}$ & $7.62 \pm 0.67 \mathrm{ab}$ \\
\hline
\end{tabular}

a: Significance from control group calculated by LSD at $p<0.05$.

b: Significance from Iso-HF calculated by LSD group at $p<0.05$.

\section{Markers of muscle atrophy:}

Table (3) shows that muscle atrogin relative gene expression was significantly increased, while muscle IGF-1 relative gene expression was significantly decreased in the ISO-HF group as compared to the $\mathrm{C}$ group. Upon probiotic treatment, muscle atrogin relative gene expression was significantly decreased, while muscle IGF-1 relative gene expression was significantly elevated in the Pro-T group as compared to the ISO-HF group. However, the levels of muscle IGF-1 relative gene expression in the ISO-HF group were still significantly lower than that of the $\mathrm{C}$ group.

Table (3): Muscle atrogin $(\mathrm{Pg} / \mathrm{mg})$ and Muscle IGF-1 relative gene expression in the different studied groups (mean \pm SEM).

\begin{tabular}{lccc}
\hline & Control & ISO-HF & Pro-T \\
\hline - Muscle atrogin & $168.20 \pm 14.74$ & $317.87 \pm 40.35^{\mathbf{a}}$ & $216.60 \pm 30.7 \mathbf{b}$ \\
$(\mathrm{Pg} / \mathrm{mg})$ & $1.03 \pm 0.01$ & $0.23 \pm 0.04^{\mathbf{a}}$ & $0.85 \pm 0.02 \mathbf{a b}$ \\
- Muscle IGF-1 \\
$\begin{array}{l}\text { relative gene } \\
\text { expression }\end{array}$
\end{tabular}

a: Significance from control group calculated by LSD at $p<0.05$.

b: Significance from Iso-HF group calculated by LSD group at $p<0.05$.

\section{Markers of insulin resistance and oxidative stress:}

Table (4) shows that plasma glucose, plasma insulin and HOMA-IR were significantly elevated in the ISO-HF group as compared to the C group. Upon probiotic treatment, plasma glucose, plasma insulin and HOMA-IR were significantly lowered in the Pro-T group as compared to the ISO-HF group, although that the plasma glucose was still significantly higher in the Pro-T group compared to that of the $\mathrm{C}$ group.

Further, muscle IRS-1 relative gene expression was significantly decreased, while muscle NADPH oxidase relative gene expression was significantly increased in the ISO-HF group compared to the $\mathrm{C}$ group. On the other hand, muscle IRS-1 relative gene expression showed a significant increase, while muscle NADPH oxidase relative gene expression showed a significant decrease in the Pro$\mathrm{T}$ group compared to the ISO-HF group, although the level of both parameters was still significantly different from that of the $\mathrm{C}$ group.

Table (4): Plasma glucose (m mol/l), plasma insulin ( JUL' HOMA IR, muscle IRS-1 relative gene expression and muscle NADPH oxidase relative gene expression in the different studied groups (mean \pm SEM).

\begin{tabular}{lccc}
\hline & Control & ISO-HF & Pro-T \\
\hline • Plasma glucose (mmol/1) & $6.94 \pm 0.48$ & $15.11 \pm 1.1^{\mathbf{a}}$ & $9.61 \pm 0.64^{\mathbf{a b}}$ \\
- Plasma insulin ( $\mathbf{L} \mathrm{L})$ & $9.46 \pm 0.36$ & $18.11 \pm 1.56^{\mathbf{a}}$ & $12.00 \pm 0.82^{\mathbf{b}}$ \\
- HOMA IR & $2.94 \pm 0.26$ & $12.11 \pm 3.35^{\mathbf{a}}$ & $5.17 \pm 0.53 \mathbf{b}$ \\
- Muscle IRS-1 relative gene & $1.03 \pm 0.01$ & $0.23 \pm 0.03^{\mathbf{a}}$ & $0.68 \pm 0.04^{\mathbf{a b}}$ \\
$\begin{array}{l}\text { expression } \\
\text { - Muscle NADPH oxidase }\end{array}$ & $1.09 \pm 0.01$ & $5.81 \pm 0.46^{\mathbf{a}}$ & $3.48 \pm 0.36^{\mathbf{a b}}$ \\
relative gene expression & & & \\
\hline
\end{tabular}

a: Significance from control group calculated by LSD at $p<0.05$.

b: Significance from Iso-HF group calculated by LSD group at $p<0.05$. 
(A) Body weight gain \%

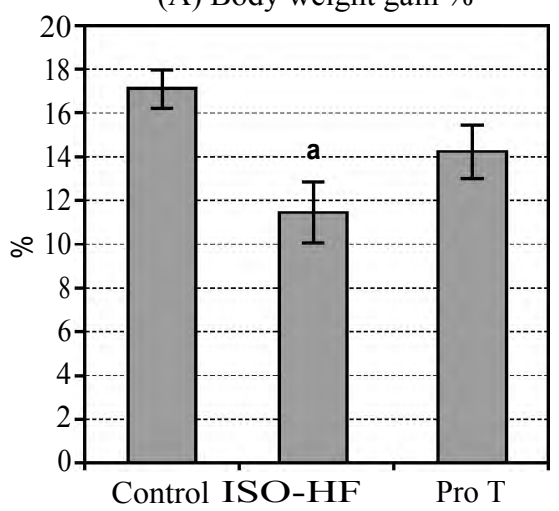

(B) Gastrocnemius Muscle weight

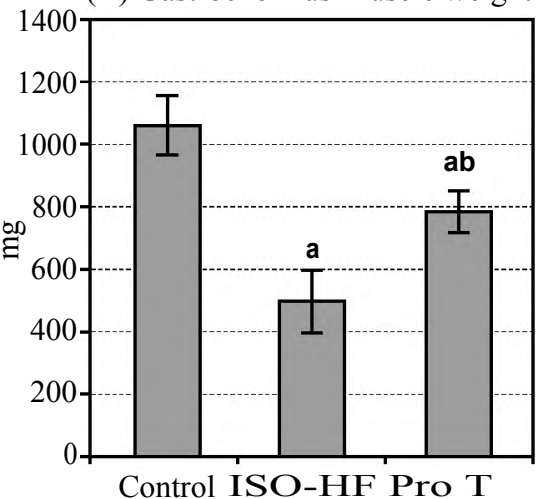

(C) Muscle/body weight ratio

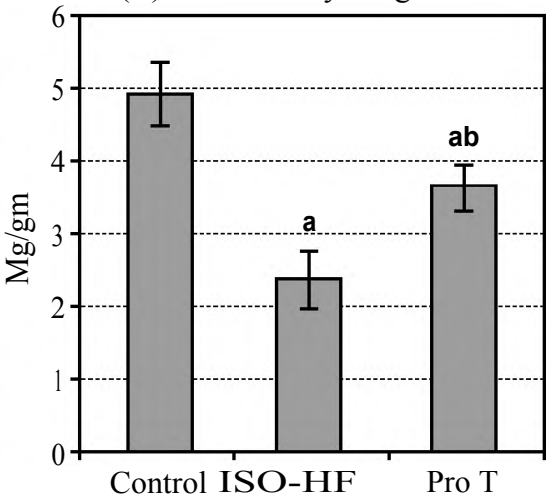

Fig. (1): (A) Body weight gain \%, (B) Absolute lower limb gastrocnemius muscle, (C) Lower limb gastrocnemius muscle to body weight ratio $(\mathrm{Ms} / \mathrm{BW})(\mathrm{mg} / \mathrm{g})$ in the different studied groups.

Fig. (1A) shows a significant decrease in body weight gain $\%$ only in the ISO-HF group compared to the $\mathrm{C}$ group. Fig. (1B) and Fig. (1C) show a significant decrease in the absolute lower limb gastrocnemius muscle weight and in the gastrocnemius muscle weight to body weight ratio in the ISO-HF group compared to

(A) Whole heart weight

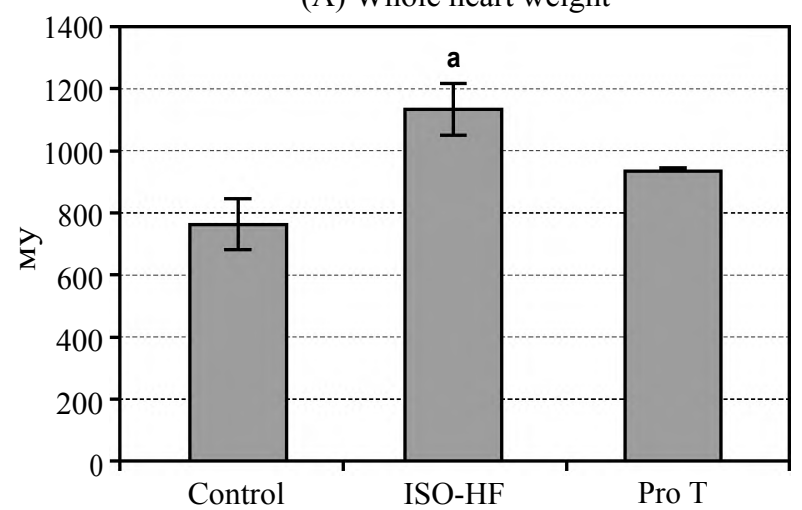

(C) Left ventricle weight

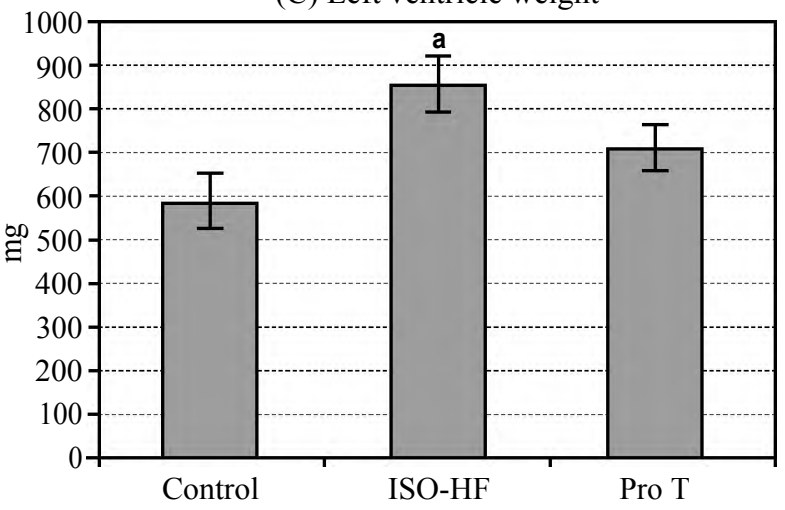

the $\mathrm{C}$ group. Pro-T group showed a significant increase in both of the absolute lower limb gastrocnemius muscle weight and in the gastrocnemius muscle weight to body weight ratio compared to the ISO-HF group, although their levels were still significantly lower than that of the $\mathrm{C}$ group.

(B) Whole heart/body weight ratio

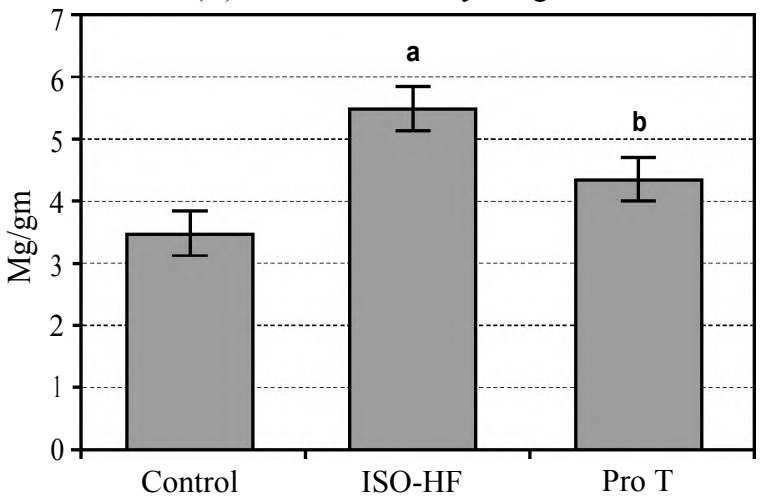

(D) Left ventricle/body weight ratio

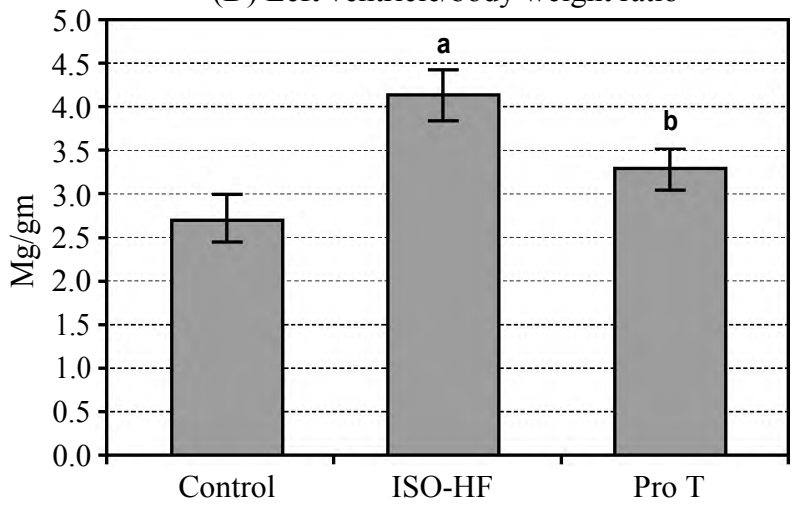

Fig. (2): (A) Whole heart weights (mg) and (B) Whole heart to body weight ratio (WH/BW) (mg/g), (C) Left ventricle, (D) Left Ventricle to Body Weight ratio (LV/BW) $(\mathrm{mg} / \mathrm{g})$ in the different studied groups.

Fig. (2A) and Fig. (2B) show a significant increase in the whole heart weight and in the heart weight to body weight ratio in the ISO-HF group compared to the $\mathrm{C}$ group. Moreover, only the heart 
weight to body weight ratio was significantly decreased in the Pro-T group compared to the ISOHF group.

Fig. (2C) and Fig. (2D) show a significant increase in the left ventricle weight and in the left ventricle to body weight ratio in the ISO-HF group

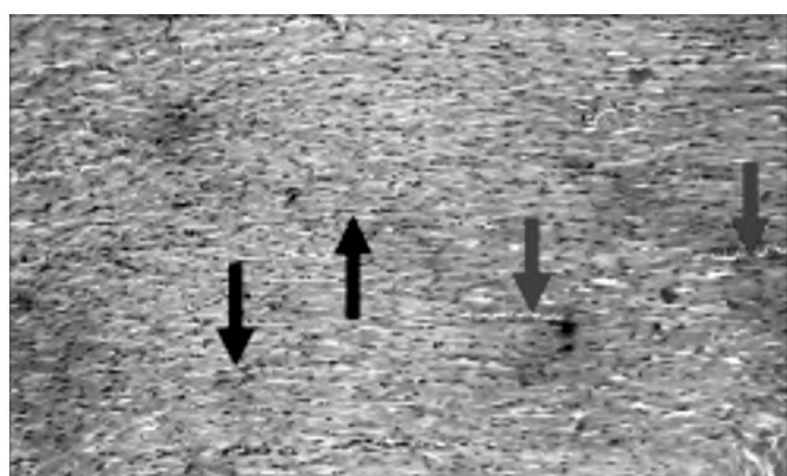

Fig. (3A): (Control group): Cardiac wall showing viable cardiac muscle fibers (black arrows) with scattered congested blood vessels (blue arrows) (H \& E X200).
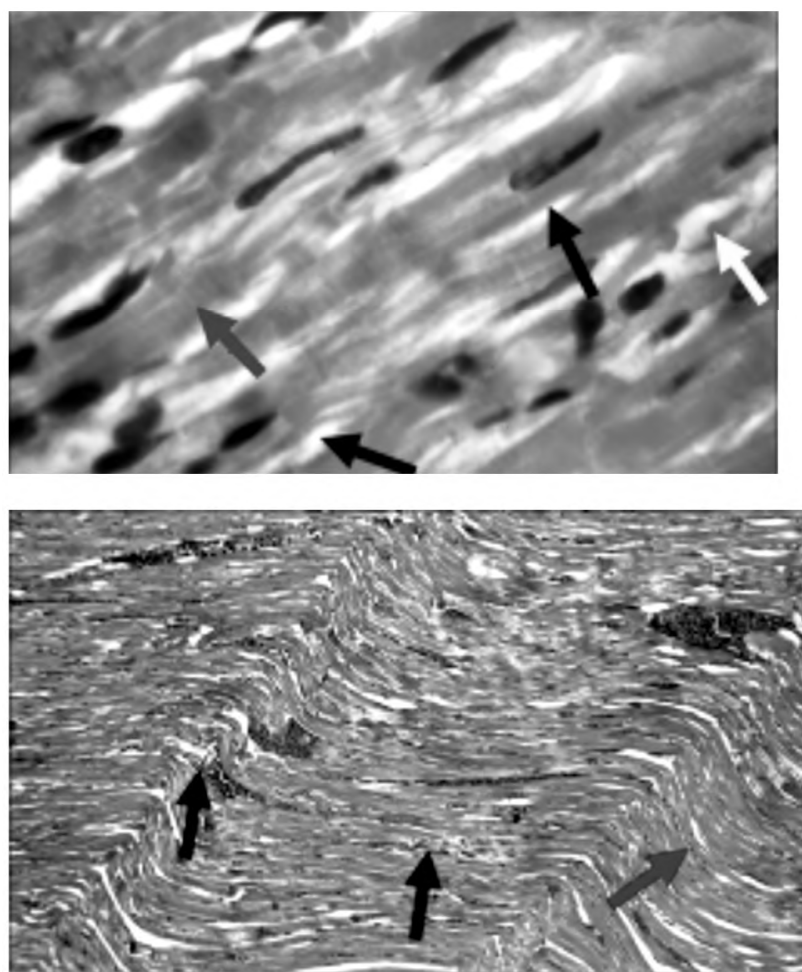

Fig. (4A): (Control group): Cardiac wall showing normal collagen distribution arround blood vessels (black arrows) and in between muscle fibers (blue arrow) (Masson trichrom stain X200).

Fig. (3A, B \& C) show $\mathrm{H} \& \mathrm{E}$ stained sections of cardiac muscle of the control group. Cardiac wall showed viable cardiac muscle fibers with distinct cell borders and central oval/elongated nuclei, apparent cross striations, and scattered congested blood vessels. compared to the $\mathrm{C}$ group. Upon treatment with probiotics, the left ventricle to body weight ratio was significantly decreased in the Pro-T group compared to the ISO-HF group.

\section{Results of histopathological examination:}

\section{Histopathological examination of cardiac muscle:}

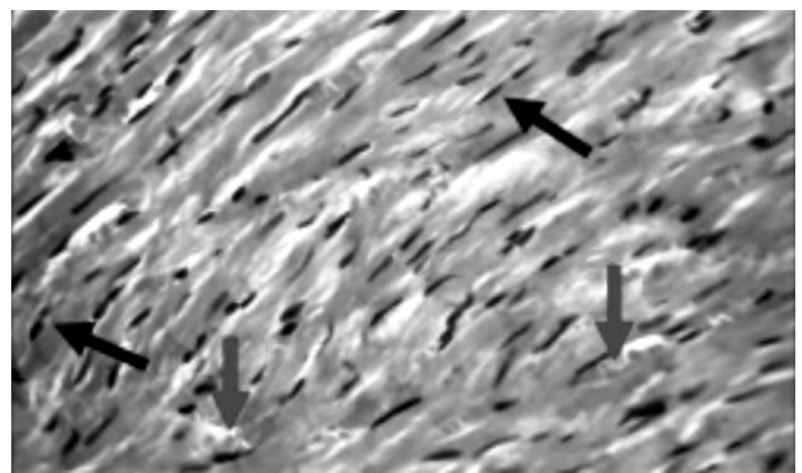

Fig. (3B): (Control group): High power view showing viable cardiac muscle fibers with distinct cell borders and central oval/elongated nuclei (black arrows). And scattered congested blood vessels (blue arrows) (H \& E X400).

Fig. (3C): (Control group): Higher power view showing viable cardiac muscle fibers with distinct cell borders and central oval/elongated nuclei (black arrows). And scattered congested blood vessels (yellow arrows) (H \& E X1000).

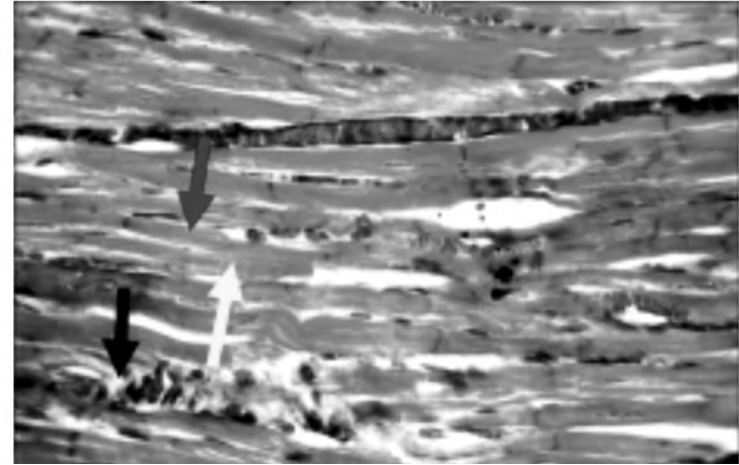

Fig. (4B): (Control group): High power view showing normal collagen distribution arround blood vessels (black arrows) and around muscle fibers (endomysium) (blue arrow) with apparent cross striations (yellow arrow) (Masson trichrom stain X400).

Fig. (4A \& B) show Masson trichrom stained sections of cardiac muscle of the control group. Cardiac wall showed normal collagen distribution around blood vessels and in between muscle fibers (endomysium) with apparent cross striations. 


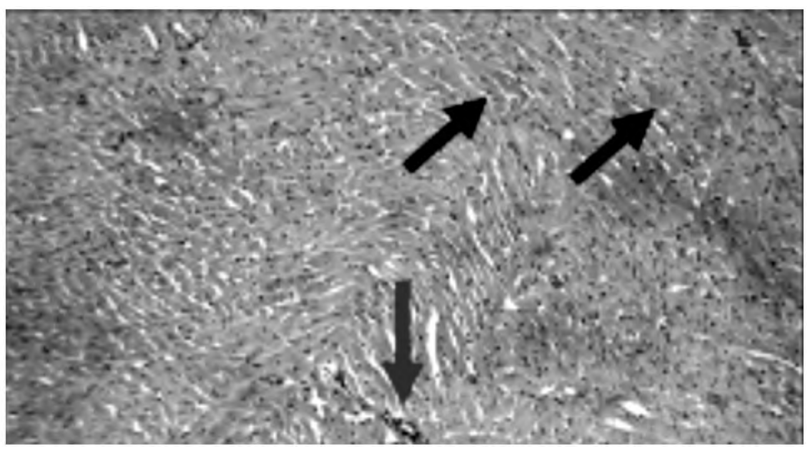

Fig. (5A): (ISO-HF group): Cardiac wall showing scattered cardiac muscle fibers with bright eosinophilic cytoplasm (black arrows) with few narrow blood vessels (blue arrow) (H \& E X200).

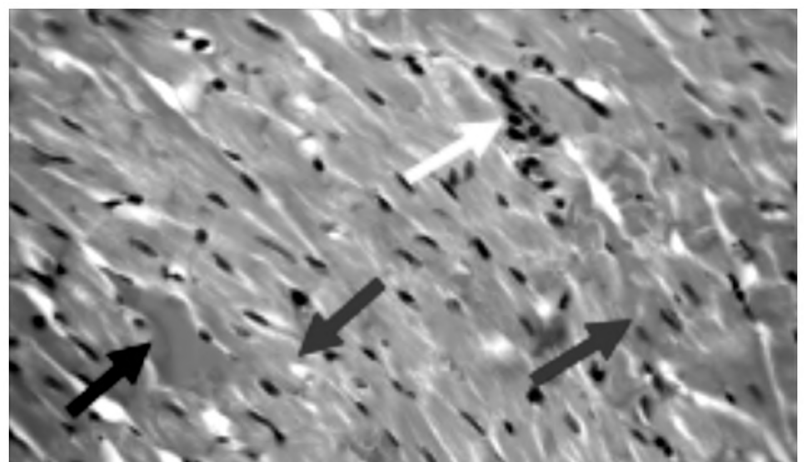

Fig. (5C): (ISO-HF group): Another view showing necrotic cardiac muscle fibers with bright eosinophilic cytoplasm and no nuclei (black arrow) with cytoplasmic vacuoles (blue arrow), and aggregate of inflammatory cells (yellow arrow) (H \& E X400).

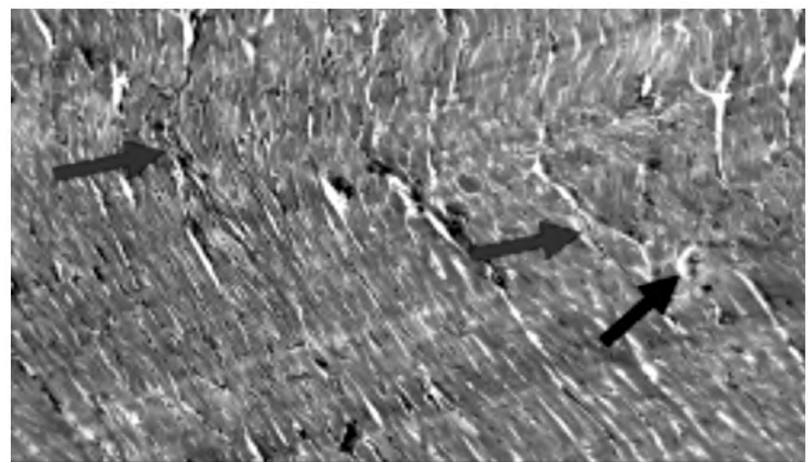

Fig. (6A): (ISO-HF group): Cardiac wall showing normal collagen distribution around blood vessels (black arrow) and thick irregular collagen fibers in between muscle fibers (blue arrows) (Masson trichrom stain X200).

Fig. (5A, B, C \& D) show H \& E stained sections of cardiac muscle of the ISO-HF group. Cardiac wall showed scattered necrotic cardiac muscle fibers with no nuclei and others with bright eosinophilic cytoplasm, pyknotic nuclei and intra-

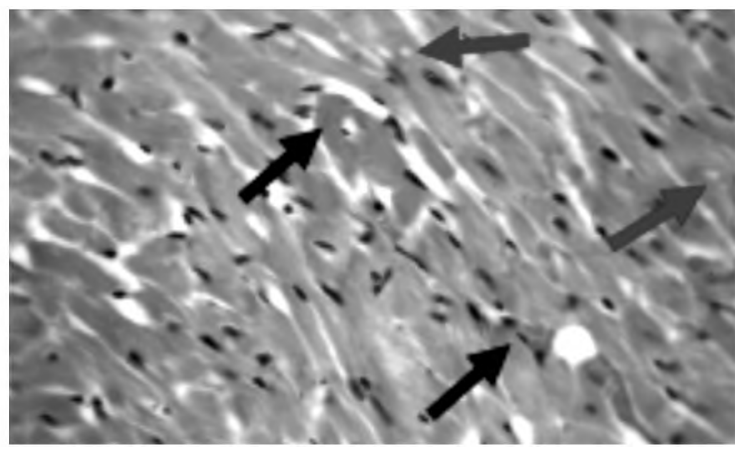

Fig. (5B): (ISO-HF group): High power view showing scattered distorted cardiac muscle fibers with bright eosinophilic cytoplasm and pyknotic nuclei (black arrows) with cytoplasmic vacuoles (blue arrow) (H \& E X400).

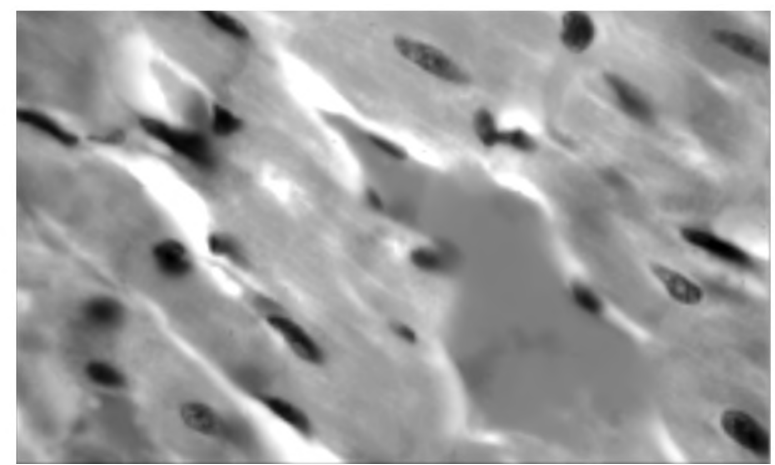

Fig. (5D): (ISO-HF group): Higher power view showing necrotic cardiac muscle fibers with bright eosinophilic cytoplasm and no nuclei (black arrows) with cytoplasmic vacuoles (blue arrow) (H \& E X1000).

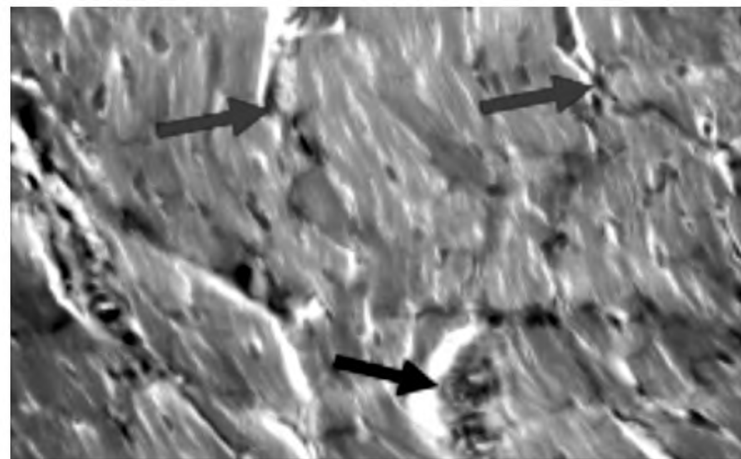

Fig. (6B): (ISO-HF group): High power view showing normal collagen distribution around blood vessels (black arrow) and thick irregular collagen fibers in between muscle fibers (endomysium) (blue arrow) (Masson trichrom stain $\mathrm{X} 400)$.

cytoplasmic vacuoles, aggregates of inflammatory cells, and few narrow blood vessels.

Fig. (6A \& B) show Masson trichrom stained sections of cardiac muscle of the ISO-HF group. 
Cardiac wall showed normal collagen distribution around blood vessels and thick irregular collagen fibers in between muscle fibers (endomysium).

Fig. (7A, B, C \& D) show H \& E stained sections of cardiac muscle of the Pro-T group. Cardiac wall showed viable cardiac muscle fibers with distinct cell borders and central oval/elongated

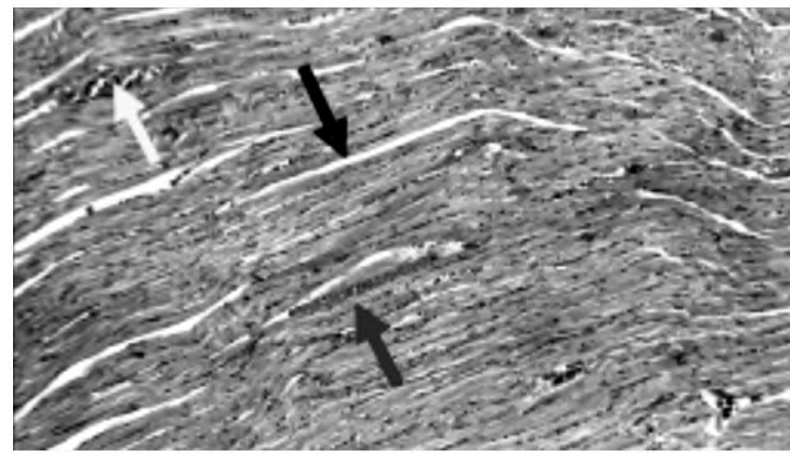

Fig. (7A): (Pro-T group): Cardiac wall showing viable cardiac muscle fibers (black arrows), and congested blood vessels (blue arrow) with areas of hemorrhage (yellow arrow) (H \& E X200).

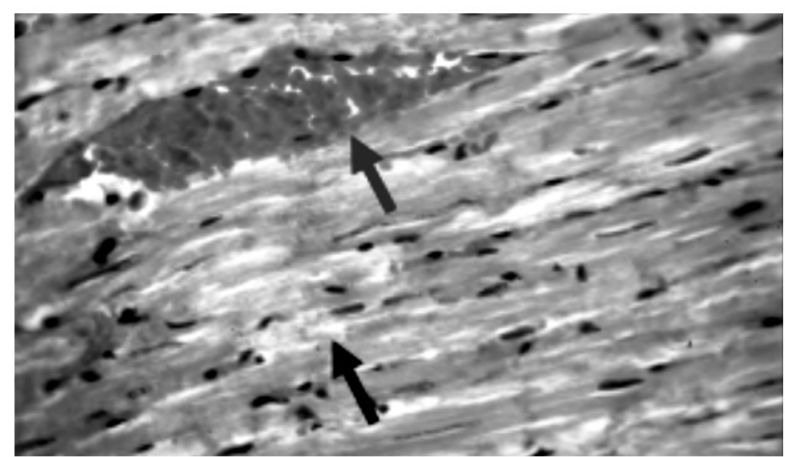

Fig. (7C): (Pro-T group): Another view showing viable cardiac muscle fibers with edematous cytoplasm (black arrows), and area of hemorrhage (blue arrow) (H \& E X400).

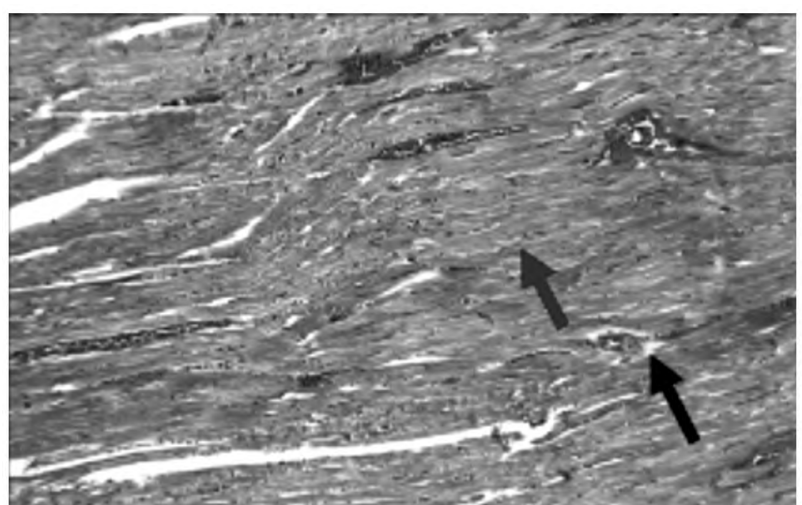

Fig. (8A): (Pro-T group): Cardiac wall showing normal collagen distribution around blood vessels (black arrow) and in between muscle fibers (blue arrow) (Masson trichrom stain $\mathrm{X} 200$ ). nuclei, cytoplasmic edema with fairly apparent cross striations, and congested blood vessels with areas of hemorrhage.

Fig. (8A \& B) show Masson trichrom stained sections of cardiac muscle of the Pro-T group. Cardiac wall showed normal collagen distribution around blood vessels and in between muscle fibers (endomysium).

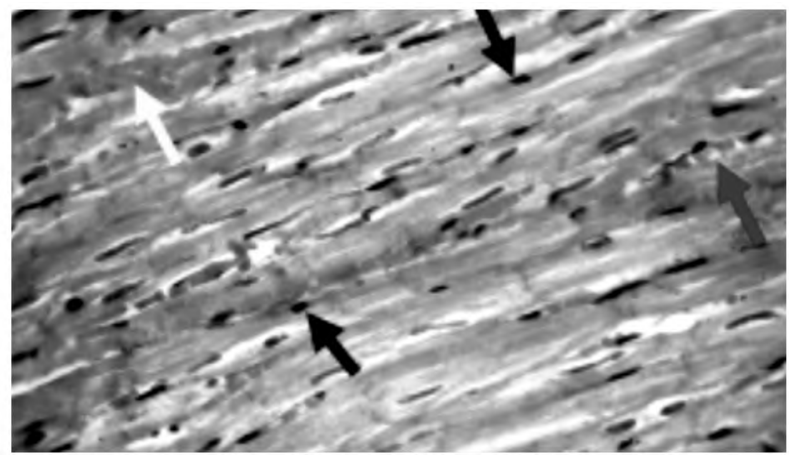

Fig. (7B): (Pro-T group): High power view showing viable cardiac muscle fibers with distinct cell borders and central oval/elongated nuclei (black arrows), and congested blood vessels (blue arrows) with areas of hemorrhage (yellow arrow) (H \& E X400)

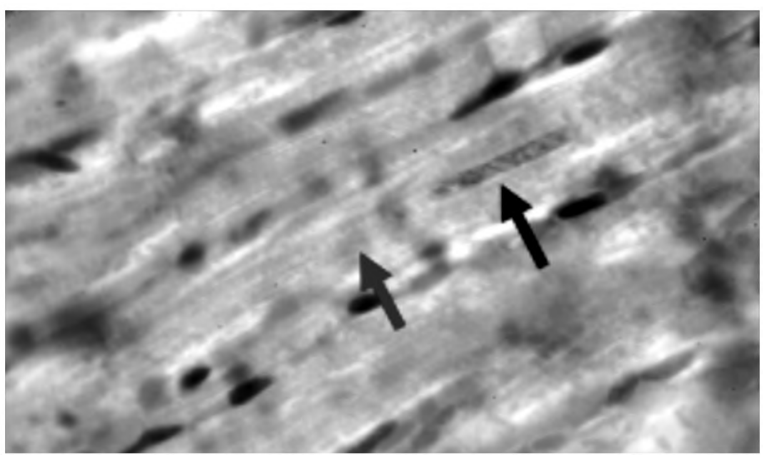

Fig. (7D): (Pro-T group): Higher view showing viable cardiac muscle fibers with oval/elongated nuclei (black arrows), and fairly apparent cross striations (blue arrows) (H \& E $\mathrm{X}$ 1000).

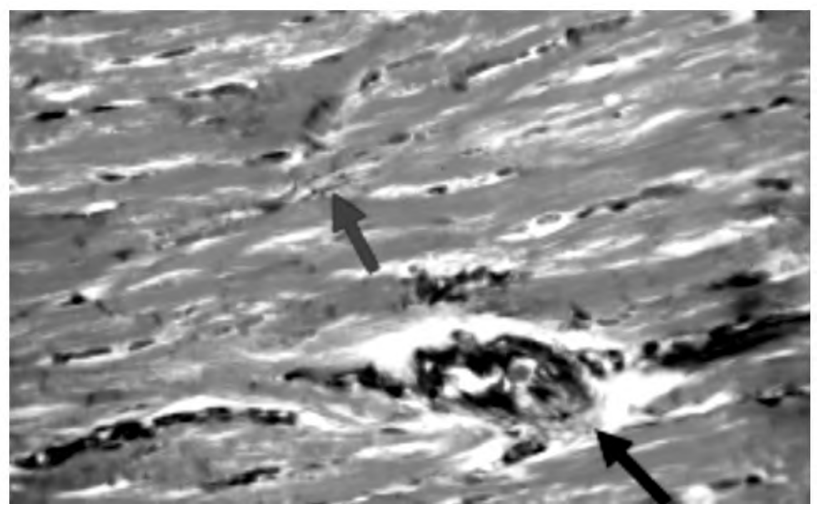

Fig. (8B): (Pro-T group): High power view showing normal collagen distribution around blood vessels (black arrows), and in between muscle fibers (endomysium) (blue arrows) (Masson trichrom stain X400). 
Histopathological examination of skeletal muscle:

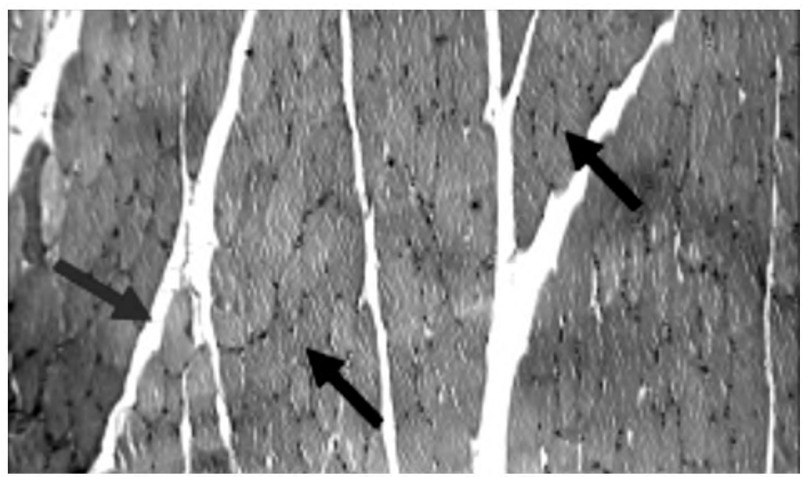

Fig. (9A): (Control group): Skeletal muscle tissue showing average transverse muscle fibers with distinct cell borders, average cytoplasm and peripheral oval nuclei (black arrows) in average loose connective tissue (blue arrow) (H \& E X200).

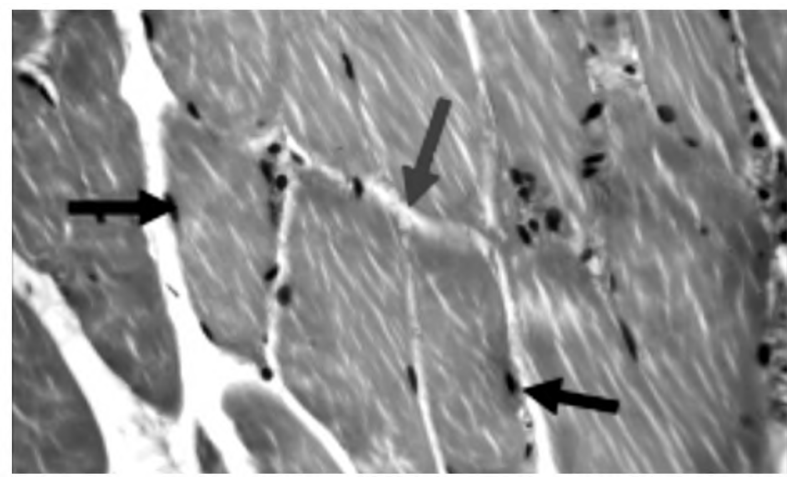

Fig. (9B): (Control group): High power view showing average transverse muscle fibers with distinct cell borders, average cytoplasm and peripheral oval nuclei (black arrows), and average edomysium (blue arrow) (H \& E X400).

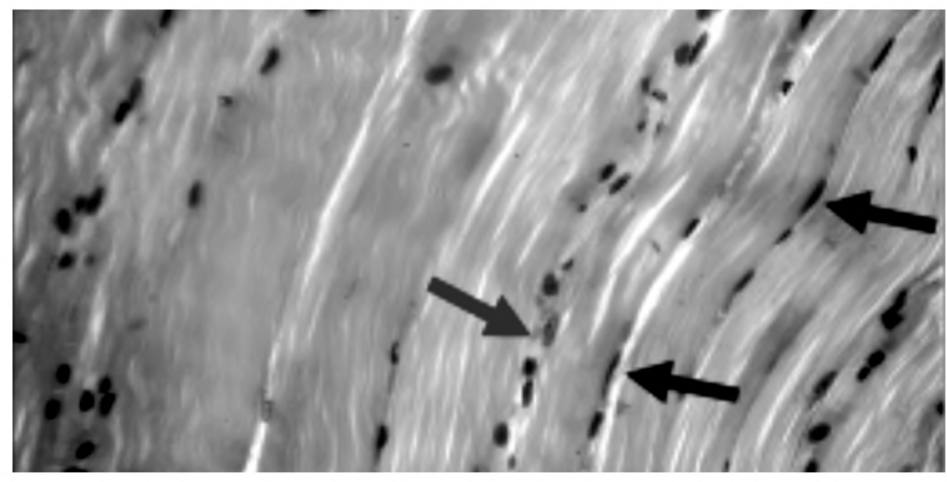

Fig. (9C): (Control group): Another view showing average longitudinal muscle fibers with distinct cell borders, average cytoplasm and peripheral oval nuclei (black arrows), and average edomysium (blue arrow) (H \& E X400).

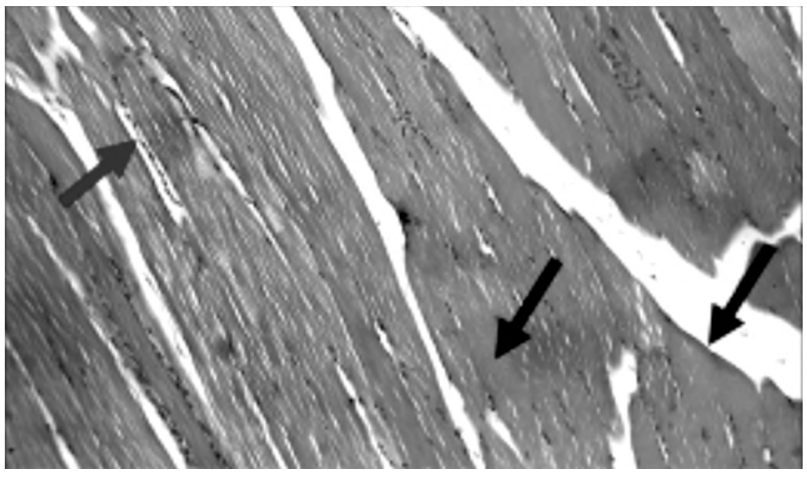

Fig. (10A): (ISO-HF group): Skeletal muscle tissue showing longitudinal muscle fibers with ill-defend cell borders and bright eosinophilic cytoplasm (black arrows) in average loose connective tissue (blue arrow) (H \& E X200).

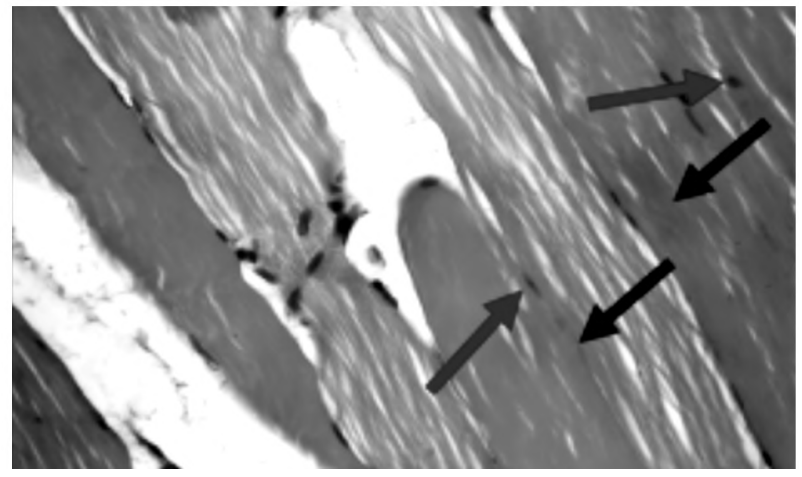

Fig. (10B): (ISO-HF group): High power view showing longitudinal muscle fiber with ill-defend cell borders, bright eosinophilic cytoplasm (black arrows) and small pyknotic nuclei (blue arrow) (H \& E X400).

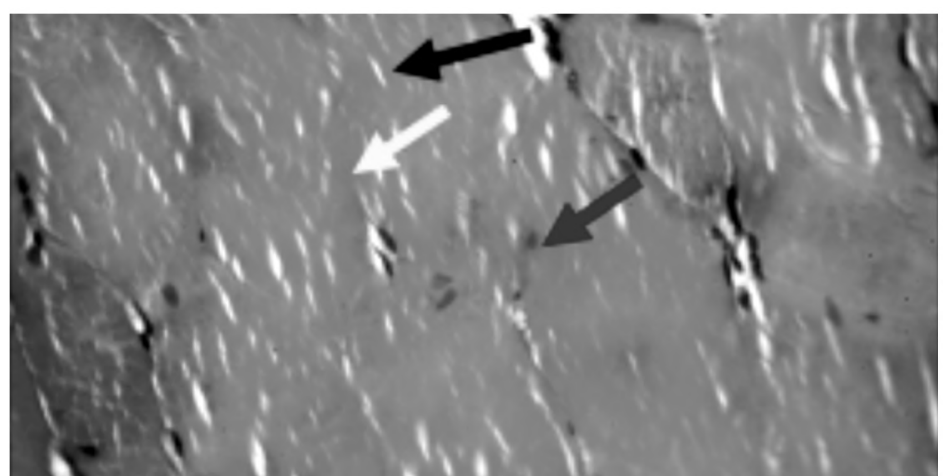

Fig. (10C): (ISO-HF group): Another view showing transverse muscle fibers with no cell borders, bright eosinophilic cytoplasm (black arrows) and small pyknotic nuclei (blue arrows), and other areas showing no nuclei (yellow arrow) (H \& E X400). 
Fig. (9A, B \& C) show $\mathrm{H} \& \mathrm{E}$ stained sections of skeletal muscle of the control group. Skeletal muscle showed average muscle fibers with distinct cell borders, average cytoplasm and peripheral oval nuclei in average loose connective tissue.

Fig. (10A, B \& C) show H \& E stained sections of skeletal muscle of the ISO-HF group. Skeletal muscle showed muscle fibers with ill-defend and

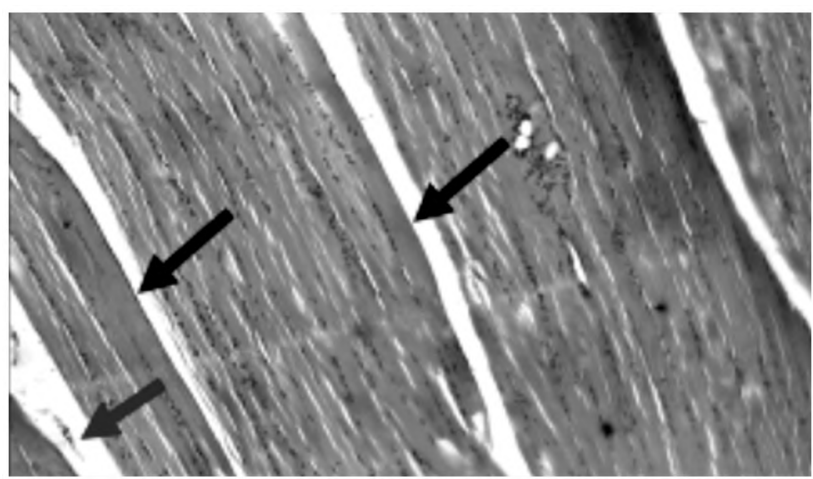

Fig. (11A): (Pro-T group): Skeletal muscle tissue showing longitudinal muscle fibers with distinct cell borders and slightly bright eosinophilic cytoplasm (black arrows) in average loose connective tissue (blue arrow) (H \& E X200). no cell borders, bright eosinophilic cytoplasm with small pyknotic nuclei and no nuclei in other areas.

Fig. (11A, B \& C) show H \& E stained sections of skeletal muscle of the Pro-T group. Skeletal muscle showed muscle fibers with distinct cell borders, few showed bright eosinophilic cytoplasm with small pyknotic nuclei in average loose connective tissue.

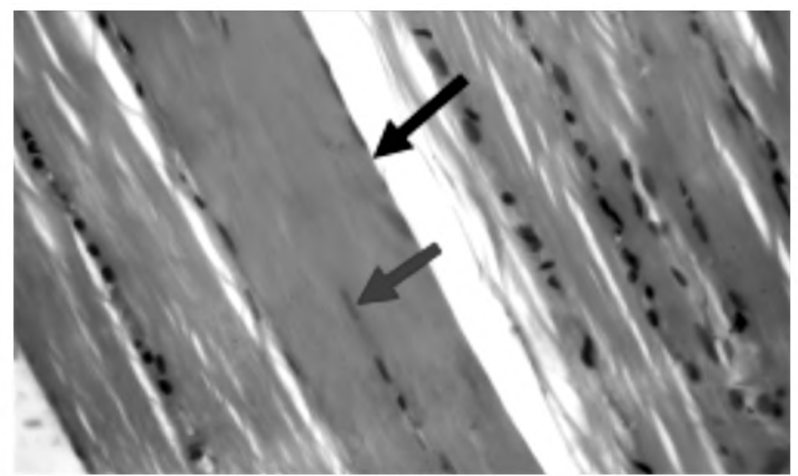

Fig. (11B): (Pro-T group): High power view showing longitudinal muscle fibers with distinct cell borders, bright eosinophilic cytoplasm (black arrows) and small pyknotic nuclei (blue arrow) (H \& E X400).

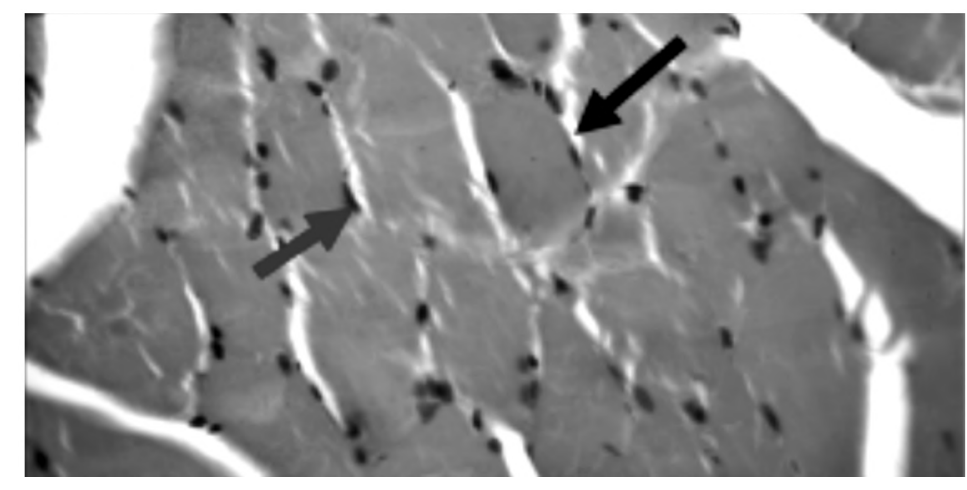

Fig. (11C): (Pro - T group): Another view showing transverse muscle fibers with distinct cell borders, slightly bright eosinophilic cytoplasm (black arrows) and peripheral oval nuclei (blue arrow) (H \& E X400).

\section{Discussion}

The present study elucidates the effect of probiotics on the skeletal muscle atrophy in Isoproterenol-induced heart failure rat model.

Cardiac insult was proved in the Isoproterenolinduced Heart Failure (ISO-HF) group by the significant increase in cardiac tissue Brain Natriuretic Peptide (BNP) and the significant increase in plasma level of angiotensin-II (Ang-II). ISOinduced HF model was chosen due to its simplicity and usefulness in studying the underlying pathophysiological processes of $\mathrm{HF}$ at the cellular and molecular levels and in examining the possible therapeutic interventions [29]. ISO injection caused cardiotoxic effects due to beta adrenergic receptors over-simulation and renin-angiotensin system overactivation leading to ischemia, oxidative stress, calcium overload and heart failure [29]
The significant increase in cardiac peptide BNP is related to cardiomyocyte stretching and elevated angiotensin II and can serve as a diagnostic marker for the impaired myocardial function [30]. Earlier, Mukoyama et al., [31] recorded higher BNP concentrations in cardiac ventricles in patients and in animals with cardiac stress. Also, plasma BNP has been correlated with the severity of left ventricular dysfunction and remodeling [32].

Further, ISO-HF group showed a significant increase in plasma Ang-II. This increase could be attributed to the excessive administration of ISO as it results in a sympatho-excitatory state, with increased activity and expression of Angiotensin Converting Enzymes (ACE) and the subsequent rise in the plasma Ang-II levels [33]. Haung et al., [20] added that large dose of ISO enhanced angiotensin expression and was accompanied by necro- 
sis, hyperplasia and myocardial fibrosis that impair myocardium pump function in rats.

This agrees with the present study. In $\mathrm{H} \& \mathrm{E}$ stained cardiac muscle of the ISO-HF group, histopathological changes in the form of scattered necrotic cardiac muscle fibers with no nuclei and with bright eosinophilic cytoplasm and intracytoplasmic vacuoles and aggregates of inflammatory cells were detected. Moreover, thick irregular collagen fibers in between muscle fibers were observed in Masson trichrom stained cardiac muscle. This was accompanied by the significant increase in the absolute whole heart weight, the left ventricle weight and their ratio to body weight in the ISO-HF group of the present study denoting hypertrophy.

These findings could be explained by the excessive and persistent $\beta$-adrenergic receptor activation or the myocardial oxidative stress and inflammation induced by ISO [34] .

Cardiac hypertrophy, remodeling and fibrosis are a consequence of the elevated Ang II and BNP. Systemic and local Ang II-induced hypertrophic effects seem to be related to increased reactive oxygen species-factor nuclear kappa B-matrix metaloproteinases pathway, Tumor Necrosis Factor (TNF-a) and the profibrotic transforming growth factor (TGF- 3 ) that increase collagen deposition and myocytes hypertrophy [35]. Also, cardiomyocyte hypertrophy was associated with increased expression of ventricular BNP, which may be related to increasing transforming growth factor (TGF)-b expression [36]

Absolute lower limb gastrocnemius muscle weight and gastrocnemius muscle weight to body weight ratio were significantly decreased in the ISO-HF group. This denotes atrophic skeletal muscle changes that may accompany heart failure and if it is severe it is referred to as cardiac cachexia. This condition was confirmed by the histopathological picture of skeletal muscle that shows illdefend muscle fibers that lack cell borders and have bright eosinophilic cytoplasm with small pyknotic nuclei and no nuclei in other areas. In addition, body weight gain \% was significantly decreased. Collectively, these findings point to the atrophic and the fibrotic effects of ISO-induced $\mathrm{HF}$ on the skeletal muscle.

Several experimental and clinical HF studies confirmed the presence of skeletal muscle alterations in HF. These alterations include atrophy, fibrosis, contractile dysfunction and decreased oxidative capacity [37]. The increased Ang-II is a major cause of skeletal muscle atrophic changes observed in this group.

Previous experimental studies have shown that Ang-II induced atrophy of rodents hind limb muscle [38]. Ang II can either impair muscle formation by inhibiting Phospho-Inositide 3-Kinase (PI3K)-Akt cascade phosphorylaration, a key molecule in protein synthesis, and by blunting the intracellular anabolic IGF- 1 signaling pathway or can induce muscle atrophy by inducing proteolytic E3 ubiquitin ligase atrogin-1 [39]. This agrees with the significant reduction in skeletal muscle IGF-1 and the IGF1 receptor Insulin Receptor Substrate 1 (IRS-1) together with the significant increase in skeletal muscle atrogin-1 relative gene expression detected in ISO-HF group compared to the control group.

IRS-1 stimulation suppresses E3 ubiquitinprotein ligases and prevents the activation of myostatin/SMAD pathway that mediates muscle proteolysis [3]. Therefore, blunting of IRS 1 signaling not only leads to an inhibition of protein synthesis but also causes concurrent induction of proteolysis. Moreover, Ang II inhibits skeletal muscle stem (satellite) cell proliferation, leading to reduced muscle regenerative capacity [39]

The sustained sympathetic activity together with high Ang II levels in heart failure can initiate a vicious circle of oxidative stress, inflammation and apoptosis leading to the activation of transcription factors nuclear factor $\kappa \mathrm{B}$ which induce muscle atrogin- 1 expression and lead to muscle atrophy [3]. This oxidative stress state was detected in this study, as the NADPH oxidase relative gene expression was significantly increased in ISO-HF group. Similarly, Kadoguchi et al., [40] . assured that Nox activation is associated with AII-induced muscle wasting.

Further, cellular damage and increased inflammatory mediators in HF have shown to decrease IRS-1 expression in muscle, thus predisposing to hyperglycemia and insulin resistance [3]

The significant increase in plasma glucose, plasma insulin and HOMA-IR, concomitant with the significant decrease in IRS-1 relative gene expression in the ISO-HF group of the present study reflect the development of insulin resistance state. This ISO-HF induced insulin resistance is due to elevated levels catecholamine [41]. Chronic beta adreno-receptor activation, by excessive ISO administration in the present study, results in persistent activation of Akt through PKA/Ca2+ and PI3K-dependent pathways, thus decreases GLUT4 expression and translocation to the plasma mem- 
brane, and this impairs the ability of insulin to facilitate glucose uptake [42]. Moreover, Ang IIinduced endothelial dysfunction, increased reactive oxygen species production and reduction of GLUT4 augment the insulin resistance state [43]. The developed insulin resistance and the loss of the anabolic effect of insulin contribute to worsening of the muscle state and the subsequent skeletal muscle atrophy, which was detected in the ISO-HF group.

In the probiotic treated group, cardiac insult markers as cardiac tissue BNP and plasma Ang-II were significantly decreased compared to the ISOHF group. Although not reaching the values of the control group, this decrease in the markers of cardiac insult reflect the beneficial cardiac health promoting effects of probiotics.

The decrease in plasma level of Ang-II in the Pro-T group could be explained by the ability of the probiotic strains to release bioactive peptides with ACE inhibitory activity, thus reducing the formation of Ang-II. Previous studies on the antihypertensive effects of probiotics explained these effects by the release of ACE inhibitory peptides that powerfully inhibit the RAS [44]. Lactobacillus probiotics strain, which is one of the strained used in the probiotic preparation used in this study, is the principal probiotic involved in releasing ACE inhibitory peptide that breaks ACE into small peptides during fermentation [45]. By inhibiting ACE, with subsequent decrease in plasma Ang-II level, ventricular pressure overload is decreased and ventricular BNP production also decreased.

In $\mathrm{H} \& \mathrm{E}$ stained sections of the cardiac muscle of the Pro-T group, cardiac wall regained the distinct cell borders with fairly apparent cross striations yet, there were some congested blood vessels with areas of hemorrhage. In masson trichrome stained sections, normal collagen distribution around blood vessels and in between muscle fibers were detected. This indicates that probiotic supplementation ameliorates the fibrotic cardiac changes induced by ISO.

These findings are in line with previous reports that probiotics supplementation decreased expression of inflammatory and fibrosis proteins in rats, and subsequently promote cardiac health [46] Moreover, Lai et al., [47] assured the anti-fibrotic effects of probiotics as probiotics induced downregulation of TGF-3/MMP2, the molecular pathway responsible for cardiac fibrosis.

The anti-fibrotic and anti-hypertrophic effects of probiotic supplementation in the present study were further confirmed by the significant reduction in both whole heart weight to body weight ratio, and in the left ventricular weight to body weight ratio in the Pro-T group compared to the ISO-HF group, to become non-significant from the control group.

These results could be due to multifactorial mechanisms. The decreased plasma Ang-II and the decreased NADPH oxidase relative gene expression in skeletal muscle, reflecting the powerful antioxidant effects of probiotics, can explain these morphological improvements in the cardiac muscle structure in the Pro-T group, by blunting the predisposing factors that promote cardiac fibrosis. Similar explanations were postulated in a high fat diet-induced model of cardiac fibrosis [47]. The ACE inhibitory and the anti-fibrotic effects of probiotics supplementation observed in the present study is in accordance to [48], who explained the cardiac health promoting effects of probiotics by their ability to produce ACE-inhibitory peptides, attenuate heart failure and cardiac hypertrophy.

In Pro-T group absolute lower limb gastrocnemius muscle weight and gastrocnemius muscle weight to body weight ratio were significantly increased, compared to the ISO-HF group, although their levels were still significantly lower than that of the control group. Also, body weight gain \% was non-significantly increased than ISO-HF group, being non-significantly changed from the control.

In addition, histopathological picture of skeletal muscle showed distinct cell borders and an average loose connective tissue, compared to ill-defend and no cell borders of muscle fibers, bright eosinophilic cytoplasm with small pyknotic nuclei and no nuclei in other areas in the ISO-HF group.

These findings illustrate the improvement in the morphological picture and disappearance of the atrophic changes in the skeletal muscle in response to probiotics supplementation. This was assured by the significant decrease in the atrogin1 the muscle atrophy marker, being nonsignificantly changed from the control group.

Similar to the results of the present study, probiotic supplementation to mice resulted in decreased atrogin expression, in conjunction with the increase in muscle mass in leukemic and in healthy young mice [49]

Also, concomitant to the decrease in atrogin the Pro-T group showed a significant increase in IGF-1 and IRS relative gene expression compared to the ISO-HF group reflecting the ability of pro- 
biotics supplementation to prevent ISO-HF induced skeletal muscle atrophy.

This effect could be explained by the decrease in Ang II, based on its well known atrophic and catabolic effects on skeletal muscle, as it can decrease IGF-1/Akt signaling, and increase E3 ubiquitin ligase atrogin- 1 proteolytic pathway activity [39]. Another major mechanism by which probiotics could promote skeletal muscle health is its ability to increase IGF-1 levels. In a recent study, Yan et al., [50] demonstrated a link between gut microbiota and IGF-1 in the form of increased IGF-1 transcription in the bone by gut microbiota. Another study by Ashpole et al., [51] declared that probiotics could increase serum IGF-1 by twofolds.

The decrease in Ang-II in the Pro-T group is one of the possible mechanisms by which probiotics increase IGF-I relative gene expression, and decrease atrogin relative gene expression.

Moreover, the present study revealed that NADPH oxidase relative gene expression was significantly decreased in the Pro-T group compared to the ISO-HF group. This finding clearly demonstrates the antioxidant effect of probiotic supplementation and its ability to enhance and augment host cellular antioxidant defenses. Similarly, Lutgendorff et al., [52] declared that probiotics can enhance synthesis of antioxidant enzymes through alteration in gene expression levels in rats. In addition, a previous study reported in vitro and in vivo antioxidant activity of probiotic bacteria. They showed that probiotics increased glutathione concentration and protected rats against doxorubicin-induced oxidative damage [53]. Moreover, 5 weeks of probiotic supplementation reduced NADPH oxidase activity and reduced vascular ROS levels in spontaneous hypertensive rats [54]

In fact, this antioxidant effect could be a potential mechanistic pathway for the probiotic skeletal muscle anti-atrophic effects and cardiac muscle anti-fibrotic effects of probiotics. This claim was supported by previous studies that showed that the probiotics have antioxidant effects which could offer protection fot the cardiac muscle in a rat model of myocardial infarction [55]

A significant decrease in plasma glucose level, plasma insulin level and in HOMA-IR, concomitant with a significant increase in IRS-1 relative gene expression were detected in the Pro-T group compared to the ISO-HF group of the present study, indicating the effects of probiotic supplementation on improving insulin sensitivity and glucose homeostasis.
A recent study demonstrated significant increases in Glut-4 in adipose tissue of probiotics fed rats and correlated its expression levels with enhanced insulin sensitivity [56]. Other studies observed that probiotics decreased blood glucose levels, improved insulin sensitivity, reduced fasting glucose level, enhanced insulin release and sensitivity, and improved oral glucose tolerance in streptozotocininduced diabetic rats [56].

The interactions between probiotics and gene expression were evaluated by some studies, which suggested the ability of probiotics microbiota to upregulate GLUT-4 mRNA in rats with type II diabetes [57]. Other studies concluded that probiotics microbiota enhanced the expression of IR- [3, IRS-1 and Akt proteins, which are largely involved in the insulin-signaling pathway, and this improved glucose uptake and reduced blood glucose level [58].

In the present study, plasma insulin level was significantly decreased in the Pro-T group. This finding is similar to the finding of a study on rats that showed a decrease in the elevated insulin levels caused by high fructose diet following probiotic use [59]. However, a previous study on diabetic rats demonstrated an increase in serum insulin levels following intake of probiotic [56]. Another study has shown that probiotics improved glucose tolerance but did no change in plasma insulin levels [60]. The inconsistency between results of the present study and other studies might be due to different mechanism of occurrence of hyperglycemia in these studies; muscle atrophy vs high fructose diet vs streptozotocin.

\section{Conclusion:}

From the results of the present study, we concluded that multiple strain probiotics possess the ability to prevent ISO-induced HF adverse effects on the cardiac and the skeletal muscle. These protective effects of probiotics are mediated through ACE-inhibitory activities and antioxidant properties of probiotics. In addition, multiple strain probiotics improve insulin sensitivity and have an antihyperglycemic effect.

\section{Acknowledgment:}

The authors acknowledge Dr. Sayed Abdel Raheem, Assistant professor of Histopathology at Al-Azhar Faculty of Medicine, Cairo for scientific help in the histopathological assessment and Dr. Laila Rashed, Professor of Medical Biochemistry and Molecular Biology at Cairo University, Faculty of Medicine. 


\section{Conflict of interest:}

No conflict of interest.

\section{References}

1- SOUZA R.W., PIEDADE W.P., SOARES L.C., SOUZA P.A., AGUIAR A.F., VECHETTI-JÚNIOR I.J., CAMPOS D.H., FERNANDES A.A., OKOSHI K., CARVALHO R.F., CICOGNA A.C. and DAL-PAI-SILVA M.: Aerobic exercise training aerobic exercise training prevents heart failure-induced skeletal muscle atrophy by anti-catabolic, but not anabolic actions. PLoS One, 17; 9 (10): e110020, 2014.

2- ZHAO J.X., ZHANG H.X., LI B., FAN Q.X., XUE S.Z., ZHANG M. and KE C.Q.: Role of MLL3 in regulating cardiac stem cells following cardiac cachexia. Eur. Rev. Med. Pharmacol. Sci., 21 (21): 4924-9, 2017.

3- VON HAEHLING S., EBNER N., DOS SANTOS M.R., SPRINGER J. and ANKER S.D.: Muscle wasting and cachexia in heart failure: Mechanisms and therapies. Nat. Rev. Cardiol., 14 (6): 323-41, 2017.

4- YOSHIDA T., TABONY A.M., GALVEZ S., MITCH W.E., HIGASHI Y., SUKHANOV S. and DELAFONTAINE P.: Molecular mechanisms and signaling pathways of angiotensin II-induced muscle wasting: Potential therapeutic targets for cardiac cachexia. Int. J. Biochem. Cell Biol., 45 (10): 2322-32, 2013.

5- DEMOS-DAVIES K.M., FERGUSON B.S., CAVASIN M.A., MAHAFFEY J.H., WILLIAMS S.M., SPILTOIR J.I., SCHUETZE K.B., HORN T.R., CHEN B., FERRARA C., SCELLINI B., PIRODDI N., TESI C., POGGESI C., JEONG M.Y. and McKINSEY T.A.: HDAC6 contributes to pathological responses of heart and skeletal muscle to chronic angiotensin-II signaling. Am. J. Physiol. Heart Circ. Physiol., 307 (2): H252-H258, 2014.

6- BRINK M., PRICE S.R., CHRAST J., BAILEY J.L., ANWAR A., MITCH W.E. and DELAFONTAINE P.: Angiotensin II induces skeletal muscle wasting through enhanced protein degradation and down-regulates autocrine insulin-like growth factor I. Endocrinology, 142 (4): 1489-96, 2001.

7- DALLA LIBERA L., RAVARA B., ANGELINI A., ROSSINI K., SANDRI M., THIENE G., BATTISTA AMBROSIO G. and VESCOVO G.: Beneficial effects on skeletal muscle of the angiotensin II type 1 receptor blocker irbesartan in experimental heart failure. Circulation, 103 (17): 2195-200, 2001.

8- YANG T., SANTISTEBAN M.M., RODRIGUEZ V., LI E., AHMARI N., CARVAJAL J.M., ZADEH M., GONG M., QI Y., ZUBCEVIC J., SAHAY B., PEPINE C.J., RAIZADA M.K. and MOHAMADZADEH M.: Gut dysbiosis is linked to hypertension. Hypertension, 65 (6): 1331-40, 2015.

9- TANG W.H., KITAI T. and HAZEN S.L.: Gut Microbiota in Cardiovascular Health and Disease. Circ. Res., 120 (7): 1183-96, 2017.

10- KARBACH S.H., SCHÖNFELDER T., BRANDÃO I., WILMS E., HÖRMANN N., JÄCKEL S., SCHÜLER R., FINGER S., KNORR M., LAGRANGE J., BRANDT M., WAISMAN A., KOSSMANN S., SCHÄFER K., MÜNZEL T., REINHARDT C. and WENZEL P.: Gut Microbiota Promote Angiotensin II-Induced Arterial
Hypertension and Vascular Dysfunction. J. Am. Heart Assoc., 30; 5 (9). pii: e003698, 2016.

11-PICCA A., FANELLI F., CALVANI R., MULÈ G., PESCE V., SISTO A., PANTANELLI C., BER NABEI R., LANDI F. and MARZETTI L.E.: Gut Dysbiosis and Muscle Aging: Searching for Novel Targets against Sarcopenia Mediators of Inflammation Article ID: 7026198, 15 pages, 2018.

12- YAN J., HERZOG J.W., TSANG K., BRENNAN C.A., BOWER M.A., GARRETT W.S., SARTOR B.R., ALIPRANTIS A.O. and CHARLES J.F.: Gut microbiota induce IGF-1 and promote bone formation and growth. Proc. Natl. Acad. Sci. USA, 22; 113 (47): E7554-E63, 2016.

13-REID G., BEUERMAN D., HEINEMANN C. and BRUCE A.W.: Probiotic Lactobacillus dose required to restore and maintain a normal vaginal flora. FEMS Immunol. Med. Microbiol., 32: 37-41, 2001.

14- WHO: FAO/WHO: Evaluation of health and nutritional properties of powder milk and live lactic acid bacteria. Food and Agriculture Organization of the United Nations and World Health Organization Expert Consultation Report, 2001.

15- PERAN L., CAMUESCO D., COMALADA M., NIETO A., CONCHA A., DIAZ-ROPERO M.P., OLIVARES M., XAUS J., ZARZUELO A. and GALVEZ J.: Preventative effects of a probiotic, Lactobacillus salivarius ssp. salivarius, in the TNBS model of rat colitis. World J. Gastro. 11 (33): 5185-92, 2005.

16- LYE H.S., RAHMAT-ALI G.R. and LEONG M.T.: Mechanisms of cholesterol removal by lactobacilli under conditions that mimic the human gastro intestinal tract. Int. Dairy J., 20 (3): 169-75, 2010.

17- SHAKERIAN M., RAZAVI S.H., ZIAI S.A., KHODAIYAN F., YARMAND M.S. and MOAYEDI A.: Proteolytic and ACE-inhibitory activities of probiotic yogurt containing non-viable bacteria as affected by different levels of fat, inulin and starter culture. J. Food Sci. Technol., 52 (4): 2428-33, 2015.

18- SMITH P., WILLEMSEN D., POPKES M., METGE F., GANDIWA E., REICHARD M. and VALENZANO D.R.: Regulation of life span by the gut microbiota in the shortlived African turquoise killifish. Elife, 6. pii: e27014, 2017.

19- SALARKIA N.1, GHADAMLI L.2, ZAERI F.3 and SABAGHIAN RAD L.: Effects of probiotic yogurt on performance, respiratory and digestive systems of young adult female endurance swimmers: A randomized controlled trial. Med. J. Islam. Repub. Iran, 27 (3): 141-6, 2013.

20- HUANG D., KE J., ZHAO A., YANG Z., LIANG D. PAN J., MAO LIU M. and CHEN J.: Establishment and Evaluation of Isoproterenol Induced Chronic Heart Failure and Cardiac Remodeling Model in Rats: An Experimental Study. IJCCd, 2 (5): 45-50, 2014

21- GAN F., CHEN X., LIAO S.F., LV C., REN F., YE G. PAN C., HUANG D., SHI J., SHI X., ZHOU H. and HUANG K.: Selenium-enriched probiotics improve antioxidant status, immune function, and selenoprotein gene expression of piglets raised under high ambient temperature. J. Agric Food Chem., 21; 62 (20): 4502-8, 2014.

22- FACHIN L., MORYIA J., NEVESGÂNDARA A.L. and VIOTTO W.H.: Evaluation of culture media for counts 
of Bifidobacterium animals subsp. lactis bb 12 in yoghurt after refrigerated storage. B.J.M., 39: 357-61, 2008.

23- De MAN J.C., M. ROGOSA and M.E. SHARPE: A medium for the cultivation of lactobacilli. Int. J. Appl. Bacteriol., 23: 130-5, 1960.

24- TERZAGHI B.E. and SANDINE W.E.: Improve medium for lactic streptococci and their bacteriophages. Appl. Microbiol., 29: 807, 1975.

25- TRINDER L.: Determination of blood glucose using an oxidaseperoxidase system with a non-carcinogenic chromagen. Ann. Clin. Biochem., 1: 24-9, 1969.

26- DELAMS H.G.: Biochemical analysis of human and animal serum for monoclonal antibodies using ELISA. Biochem., 14: 214-31, 1986.

27- MATHEWS D.R., HOSKER J.P., RUDENSKI A.S., NAYLOR B.A., TREACHER D.F. and TURNER R.C.: Homeostasis model assessment: Insulin resistance and $K$ cell function from fasting plasma glucose and insulin concentrations in man. Diabetologia, 28: 412-9, 1985.

28- BANCROFT J.D. and GAMBLE M.: Theory and practice of histological techniques. 6 th ed. Philadelphia, PA: Churchill Livingstone, 2008.

29- NICHTOVA Z., NOVOTNA M., KRALOVA and STANKOVICOVA T.: Morphological and functional characteristics of models of experimental myocardial injury induced by isoproterenol. Gen. Physiol. Biophys., 31: 141-51, 2012.

30- LISY and BABAL P.: Brain natriuretic peptide--the biological marker in the diagnosis of overt congestive heart failure and myocardial ischemia. Bratisl Lek Listy, 108 (4-5): 170-3, 2007.

31- MUKOYAMA M., NAKAO K., HOSODA K., SUGA S., SAITO Y., OGAWA Y., SHIRAKAMI G., JOUGASAKI M., OBATA K., YASUE H., et al.: Brain natriuretic peptide as a novel cardiac hormone in humans. Evidence for an exquisite dual natriuretic peptide system, atrial natriuretic peptide and brain natriuretic peptide. J. Clin. Invest., 87: 1402-12, 1991.

32- MORROW D.A. and BRAUNWALD E.: Future of biomarkers in acute coronary syndromes: Moving toward a multimarker strategy. Circulation, 22; 108 (3): 250-2, 2003.

33- OLIVEIRA E. and KRIEGER J.: Chronic betaadrenoceptor stimulation and cardiac hypertrophy with no induction of circulating renin. Eur. J. Pharmacol., 520: 135-41, 2005.

34- VIJAYAN N., THIRUCHENDURAN M. and DEVARAJ S.: Anti-inflammatory and anti-apoptotic effects of Crataegus oxyacantha on isoproterenol-induced myocardial damage. Mol. Cell Biochem., 367: 1-8, 2012.

35- RESTINI C.B.A., ENGRACIA A.F., NATALIN H.M. and RIZI E.: Signaling Pathways of Cardiac Remodeling Related to Angiotensin II, Chapter 4, 51-68. In: ReninAngiotensin System-Past, Present and Future. Intech Open Publisher, 2017.

36- GONCALVES G.K., CALDEIRA De OLIVEIRA T.H. and BELO N.: Cardiac Hypertrophy and Brain Natriuretic Peptide Levels in an Ovariectomized Rat Model Fed a High-Fat Diet. Med. Sci. Monit. Basic. Res., 18 (23): 380-91, 2017.
37- LIMA A.R., MARTINEZ P.F., DAMATTO R.L., CEZAR M.D., GUIZONI D.M., BONOMO C., OLIVEIRA S.A.J., DAL-PAI SILVA M., ZORNOFF L.A., OKOSHI K. and OKOSHI M.P.: Heart failure-induced diaphragm myopathy. Cell Physiol. Biochem., 34 (2): 333-45, 2014.

38- SEMPRUN-PRIETO L.C., SUKHANOV S., YOSHIDA T., REZK B.M., GONZALEZ-VILLALOBOS R.A., VAUGHN C., MICHAEL TABONY A. and DELAFONTAINE P.: Angiotensin II induced catabolic effect and muscle atrophy are redox dependent. Biochem. Biophys. Res. Commun., 409: 217-21, 2011.

39- BACURAU A.V., CUNHA T.F., SOUZA R.W., VOLTARELLI V.A., GABRIEL-COSTA D. and BRUM P.C.: Aerobic Exercise and Pharmacological Therapies for Skeletal Myopathy in Heart Failure: Similarities and Differences. Oxid. Med. Cell Longev., 2016: 4374671, 2016.

40- KADOGUCHI T., SHIMADA K., KOIDE H., MIYAZAKI T., SHIOZAWA T., TAKAHASHI S., AIKAWA T., OUCHI S., KITAMURA K., SUGITA Y., HAMAD A.S., KUNIMOTO M., SATO-OKABAYASHI Y., AKITA K., ISODA K. and DAIDA H.: Possible Role of NADPH Oxidase 4 in Angiotensin II-Induced Muscle Wasting in Mice. Front Physiol., 9: 340-9, 2018.

41- HECK P.M. and DUTKA D.P.: Insulin resistance and heart failure. Curr. Heart Fail. Rep., 6 (2): 89-94, 2009.

42- MANGMOOL S., DENKAEW T., PHOSRI S., PINTHONG D., PARICHATIKANOND W., SHIMAUCHI T. and NISHIDA M.: Sustained betaAR stimulation mediates cardiac insulin resistance in a PKA-dependent manner. Mol. Endocrinol., 30: 118-32, 2016.

43- CABELLO-VERRUGIO C., MORALES M.G., RIVERA J.C., CABRERA D. and SIMON F.: Renin-angiotensin system: An old player with novel functions in skeletal muscle. Med. Res. Rev., 35 (3): 437-63, 2012.

44- CHEN Y., LIU W., XUE J., YANG J., CHEN X., SHAO Y., KWOK L.Y., BILIGE M., MANG L. and ZHANG H.: Angiotensin-converting enzyme inhibitory activity of Lactobacillus helveticus strains from traditional fermented dairy foods and antihypertensive effect of fermented milk of strain H9. J. Dairy Sci., 97 (11): 6680-92, 2014.

45- CHEN H., JI Z., SHU G.W. and XING H.N.: Effect of probiotic Lactobacillus strains on angiotensin I converting enzyme inhibitory activity from fermented goat milk. Adv Mat Res, 531. Trans. Tech. Publications, pp. 442-5, 2012.

46- LIN P.P., HSIEH Y.M., KUO W.W., LIN Y.M., YEH Y.L., LIN C.C., TSAI F.J., TSAI C.H., TSAI C.C. and HUANG C.Y.: Suppression of TLR-4-related inflammatory pathway and anti-fibrosis effects of probiotic-fermented purple sweet potato yogurt in hearts of spontaneously hypertensive rats. The Chinese Journal of Physiology, 56: 174-83, 2013.

47- LAI C.H., TSAI C.C., KUO W.W., HO T.J., DAY C.H., PAI P.Y., CHUNG L.C., HUANG C.C., WANG H.F., LIAO P.H. and HUANG C.Y.: Multi-Strain Probiotics Inhibit Cardiac Myopathies and Autophagy to Prevent Heart Injury in High-Fat Diet-Fed Rats. Int. J. Med. Sci., 13: 277-85, 2016.

48- ETTINGER G., MacDONALD K., REID G. and BURTON J.P.: The influence of the human microbiome and probiotics 
on cardiovascular health. Gut. Microbes., 5 (6): 719-28, 2014.

49- CHEN Y.M., WEI L., CHIU Y.S., HSU Y.J., TSAI T.Y., WANG M.F. and HUANG C.C.: Lactobacillus plantarum TWK10 supplementation improves exercise performance and increases muscle mass in mice. Nutrients, 8: 205-20, 2016.

50- YAN J., HERZOG J.W., TSANG K., BRENNAN C.A., BOWER M.A., GARRETT W.S., SARTOR B.R., ALIPRANTIS A.O. and CHARLES J.F.: Gut microbiota induce IGF-1 and promote bone formation and growth. E7554-E7563 | PNAS, 2016.

51- ASHPOLE N.M., HERRON J.C., MITSCHELEN M.C., FARLEY J.A., LOGAN S., YAN H., UNGVARI Z., HODGES E.L., CSISZAR A., IKENO Y., HUMPHREY M.B. and SONNTAG W.E.: IGF-1 regulates vertebral bone aging through sex-specific and time-dependent mechanisms. J. Bone Miner. Res., 31 (2): 443-54, 2016.

52- LUTGENDORFF F., NIJMEIJER R.M., SANDSTRÖM P.A., TRULSSON L.M., MAGNUSSON K.E., TIMMERMAN H.M., VAN MINNEN L.P., RIJKERS G.T., GOOSZEN H.G., AKKERMANS L.M. and SÖDERHOLM J.D.: Probiotics prevent intestinal barrier dysfunction in acute pancreatitis in rats via induction of ileal mucosal glutathione biosynthesis. PLoS One, 4 (2): e4512. 2009.

53- AMARETTI A., Di NUNZIO M., POMPEI A., RAIMONDI S., ROSSI M. and BORDONI A.: Antioxidant properties of potentially probiotic bacteria: In vitro and in vivo activities: Applied Microbiology and Biotechnology, 97 (2): 809-17, 2013.

54- GÓMEZ-GUZMÁN M., TORAL M., ROMERO M., JIMÉNEZ R., GALINDO P., SÁNCHEZ M., ZARZUELO M.J., OLIVARES M., GÁLVEZ J. and DUARTE J.: Antihypertensive effects of probiotics Lactobacillus strains in spontaneously hypertensive rats. Mol. Nutr. Food Res., 59 (11): 2326-36, 2015.

55- SADEGHZADEH J., VAKILI A., SAMENI H.R., SHADNOUSH M., BANDEGI A.R. and ZAHEDI KHORASANI M.: The Effect of Oral Consumption of Probiotics in Prevention of Heart Injury in a Rat Myocardial Infarction Model: A Histopathological, Hemodynamic and Biochemical Evaluation. Iranian Biomedical Journal, 21 (3): 17481, 2017.

56- MEMARRAST F., GHAFOURI-FARD S., KOLIVAND S., NODOOSHAN S.J., NEYAZI N., SADRODDINY E. and MOTEVASELI E.: Comparative evaluation of probiotics effects on plasma glucose, lipid, and insulin levels in streptozotocin-induced diabetic rats. Diabetes Metab. Res. Rev., 33: e2912, 2017.

57- LI C.1, DING Q., NIE S.P., ZHANG Y.S., XIONG T. and XIE M.Y.: Carrot juice fermented with Lactobacillus plantarum NCU116 ameliorates type 2 diabetes in rats. J. Agric Food Chem., 62 (49): 11884-91, 2014.

58- LE T.K., HOSAKA T., NGUYEN T.T., KASSU A., DANG T.O., TRAN H.B., PHAM T.P., TRAN Q.B., LE T.H. and PHAM X.D.: Bifidobacterium species lower serum glucose, increase expressions of insulin signaling proteins, and improve adipokine profile in diabetic mice. Biomed. Res., 36 (1): 63-70, 2015.

59- HSIEH F.C., LEE C.L., CHAI C.Y., CHEN W.T., LU Y.C. and WU C.S. Oral administration of Lactobacillus reuteri GMNL-263 improves insulin resistance and ameliorates hepatic steatosis in high fructose fed rats. Nutr. Metab., 10 (1): 35-49, 2013.

60- ANDERSSON U.1, BRÄNNING C., AHRNÉ S., MOLIN G., ALENFALL J., ONNING G., NYMAN M. and HOLM C.: Probiotics lower plasma glucose in the high-fat fed C57BL/6J mouse. Benefic Microbes, 1 (2): 189-96, 2010. 


\section{البروبايوتك تخفف من ضمور العضلات الهيكلية فى قصور القلب الناجم

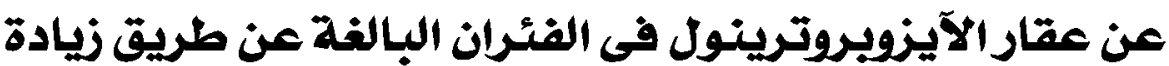

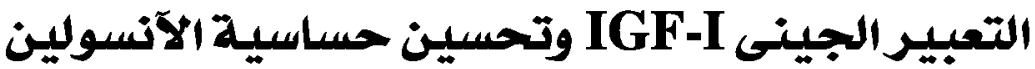

خلفية البحث: آظهرت الدراسات آن قصود عضلة القلب يصاحبه ضمور فى العضلات الهيكية ويرجع سبب هذا لدعم الإتزان فى مستوى الهرمونات والإختلال فى بكتريا الآمعاء.

الهدف من العمل: تقييم تآثير إعطاء بكتريا نافعة على حالة العضلات الهيكلية فى مرض قصود عضلة القلب الناتج عن إعطاء عقار الآيزوبروترينول مع توضيح آليات ذلك.

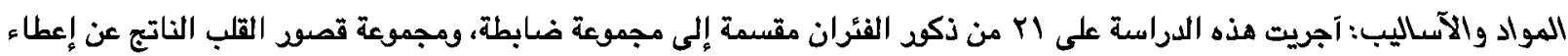

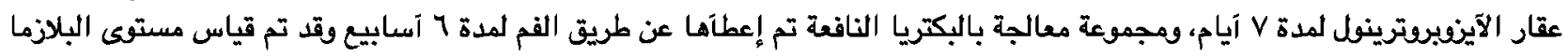

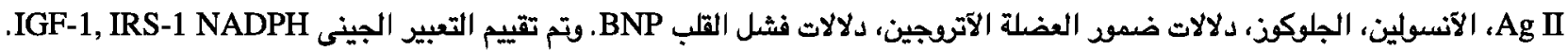
وتم ونن عضلة القلب والعضلات الهيكلية مع التحليل الهستولوجى للآلاتنسجة.

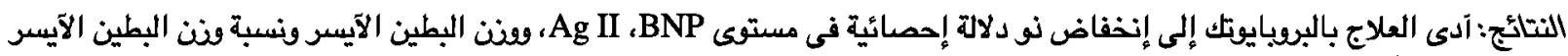

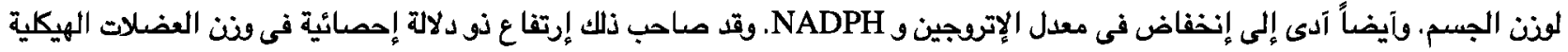

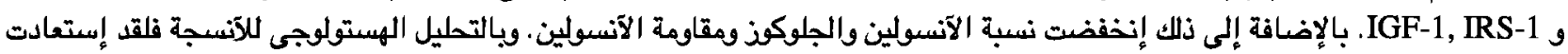
العضلات الهيكية حدودها الواضحة وقلت نسبة التليف في عضلة القلب.

الخلاصة:قدرة البويايوتك على تحسين حالة عضلة القلب والتقليل من تضخم وتليف عضلة القلب وآيضاً تحسين ضمود العضلات الهيكلية

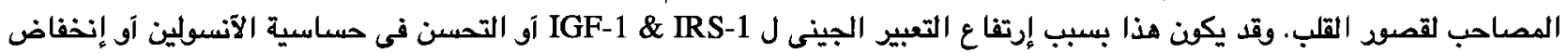

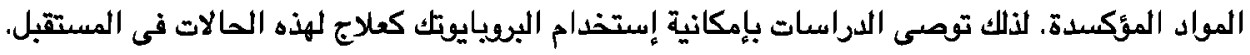

